\title{
Tectonic evolution in the Wadi Araba Segment of the Dead Sea Rift, South-West Jordan
}

\author{
U. Zain Eldeen ${ }^{1}$, D. Delvaux ${ }^{2}$, and P. Jacobs ${ }^{3}$ \\ ${ }^{1}$ Department of Geology, Al Azhar University of Gaza, P.O. Box 1277, Gaza, Palestine \\ ${ }^{2}$ Department of Geology and Mineralogy, Royal Museum for Central Africa, Leuvensesteenweg 13, B-3080 Tervuren, \\ Belgium \\ ${ }^{3}$ Department of Geology and Soil Science, Ghent University, Krijgslaan 281/S8, B-9000 Gent, Belgium
}

Received: 27 November 2000 - Revised: 29 January 2002 - Accepted: 1 February 2002

\begin{abstract}
This work presents the first palaeostress results obtained from fault-slip data along the eastern margins of the Dead Sea Rift (also named Dead Sea Transform) in South-western Jordan. Stress inversion of the fault-slip data was performed using an improved Right-Dieder method, followed by rotational optimisation. Fault-slip data (totalling 2773) include fault planes, striations and sense of movements, obtained from outcrops ranging in age from Neoproterozoic crystalline basement to Holocene sediments. The data were inverted to determine 88 different palaeostress tensors. Eight palaeostress tensor groups (stages) have been identified, ranging from the Late Neoproterozoic to the Holocene period, and have been correlated with the tectonic evolution of the Dead Sea Rift.

The new palaeostress data evidence a general clockwise rotation with time of the $\mathrm{S}_{\mathrm{Hmax}}$ axis from an E-W trend in the Cretaceous to a N-S trend in the Pleistocene. Two stages can be distinguished in this rotation. The older one marks the change of the $\mathrm{S}_{\mathrm{Hmax}}$ axis from E-W to NW- SE (about $50^{\circ}$ rotation), and took place in the Miocene. The second one illustrates the changes of the $\mathrm{S}_{\mathrm{Hmax}}$ axis from NW-SE to NNW-SSE to N-S ( $38^{\circ}$ rotation), taking place during the Pleistocene (the last $6 \mathrm{Ma}$ ). The data also show the appearance of E-W extension in the Late Pleistocene, superimposed on the Dead Sea Stress Field. We therefore suggest that the Dead Sea Rift system formed in a combination of strike-slip and dip-slip movements.
\end{abstract}

\section{Introduction}

The Dead Sea Rift, also named Dead Sea Transform, is a $1100 \mathrm{~km}$ long sinistral fault system that connects the Gulf of Suez - Red Sea spreading system to convergence zone in

Correspondence to: U. Zain Eldeen

(http://usama_zaineldeen@hotmail.com) the Taurus - Zagros mountains (Fig. 1). In terms of plate tectonics it is considered to be a plate boundary between the Arabian plate in the east and the Israel-Sinai sub-plate (part of the African plate) in the west.

The Dead Sea Rift is the major tectonic feature controlling the stratigraphic and structural evolution of the region since the Miocene. The structure and the deformation of the region have been the focus of many discussions and interpretations. Although the tectonic deformation of the region has been attributed to N-S relative motion along the Dead Sea Rift (e.g. Quennel, 1959; Freund, 1965), there are three schools of thought on the nature of movement along the Dead Sea Rift. Von Buch (1841) interpreted the Dead Sea Rift as a result of normal faulting. Picard (1943, 1965 and 1987), Bentor and Vorman (1954), Bender (1970 and 1975) and Michelson et al. (1987) supported this interpretation. Lartet (1869) interpreted the movement along the Dead Sea Rift to be strike-slip as the major movement and normal as a minor one. This interpretation was subsequently supported by Quennel (1956 and 1959), Freund (1965), Zak and Freund (1966 and 1981), Freund et al. (1968 and 1970), Neev (1975), Bartov et al. (1980), Garfunkel (1981) and Garfunkel et al. (1981). Others (Vorman, 1961; Michelson, 1982; Bahat and Rabinovitch, 1983) claim that the rift evolved as a combination of vertical (dip-slip) and horizontal (left-lateral) movement.

Because of its key position in the geology of the region, the Dead Sea Rift region and its margins have been the subject of many detailed mapping and regional structural studies (e.g. Picard, 1943; Bentor and Vorman, 1954; Quennel, 1959; De Sitter, 1962; Freund, 1965, 1970; Bender, 1968; Garfunkel, 1970, 1981; Bartov, 1974; Garfunkel and Bartov, 1977; Eyal et al., 1981; Reches et al., 1981). Comprehensive structural studies were based on small-scale structures (e.g. Letouzey and Tremolières, 1980; Reches et al., 1981; Eyal and Reches, 1983; Ron and Eyal, 1985) and on focal plane solutions of earthquakes (e.g. Ben Menahem et al., 1976; Badawy and Horvath, 1999). 


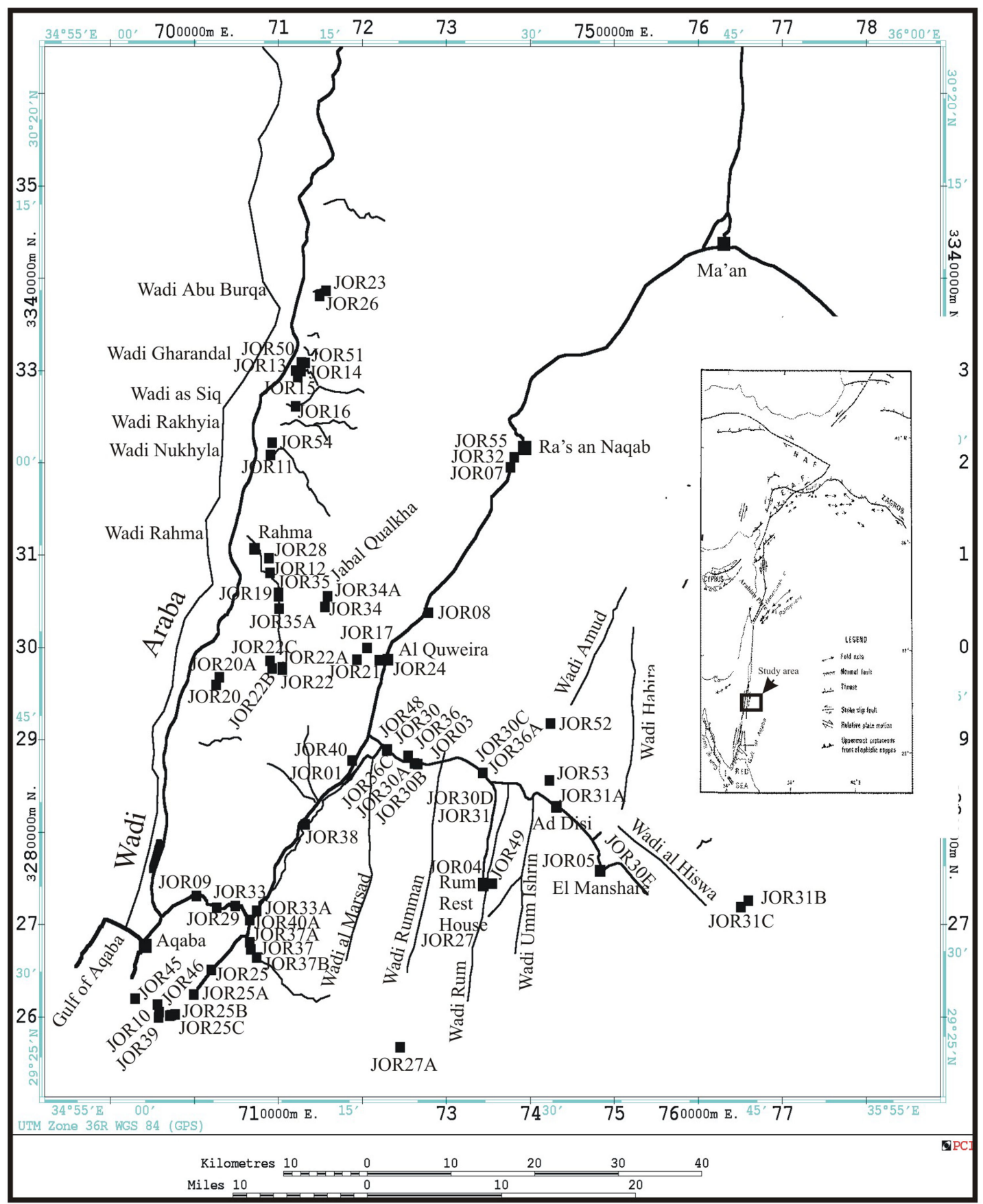

Fig. 1. Location of the established stations in the study area. Inset: location map of the study area.

\section{Aim of the study}

The controversy on the mechanics and origin of the Dead Sea Rift led us to conduct research in the southern segment of the Dead Sea Rift, on the eastern flank of southern Wadi Araba Fault in South-west Jordan. The aims of the study were to:

1. measure and analyse the structural data from the field to obtain the palaeostress tensors;

2. construct the kinematics and palaeostress evolution of the Dead Sea Rift;

3. compare the palaeostress results of the study area with those of the western margin of the rift;

4. determine the structural effects of the rift formation in the study area;

5. discuss the implication of our results on the origin of the Dead Sea Rift. 


\section{Stress fields for the Dead Sea Rift region}

Determination of the orientation of a palaeostress field is often based on the analysis of structures such as fold axes, faults with known sense of movement, tabular magmatic intrusions (mostly dykes), volcanic lineaments, veins, joints and tectonic stylolites. A reconstruction of the palaeostress field is crucial for understanding the tectonic processes that lead to the development of these structures. The determination of recent to sub-recent stress fields is based on geophysical data including focal plane solution of earthquakes, hydraulic fracturing, and borehole breakouts. Several attempts were carried out to map palaeostress fields in the Dead Sea region. All these studies have concentrated on the western side of the Dead Sea Fault System in Israel and the Sinai. For this area, an extensive set of stress data derived from fault striations, tectonic stylolites, veins with secondary mineralization, small folds and dykes has been published (e.g. Eyal and Reches, 1983; Hatzor and Reches, 1990; Eyal, 1996; Badawy and Horvath, 1999). The present study however is directed to the eastern side of the fault system, especially in South-western Jordan, for which no data on palaeostress evolution exists. Therefore our results will be the first to be introduced for the eastern side of the rift.

\section{Method of investigation}

The combined stress tensor determination and fault separation introduced here make use of the TENSOR program (Delvaux, 1993), specially designed for providing great interactivity and allowing to control all used parameters. The program should be considered as a tool for helping the operator to separate possible groups in the fault population and determine their stress tensors. It is up to the operator to make himself the final decision, taking into account the qualitative information from the field.

The inversion is based on Bott's (1959) assumption that slip on a plane occurs in the direction of the maximum resolved shear stress. The slip direction on the fault plane is inferred from frictional grooves or striations. The data used for the inversion are the strike and dip of the fault plane, the orientation of the slip line and the sense of movement on the fault plane. They are collectively referred to as fault-slip data. The fault-slip data are inverted to obtain the four parameters of the reduced stress tensor according to Angelier (1994): the principal stress axes $\sigma 1$ (maximum compression), $\sigma 2$ (intermediate compression) and $\sigma 3$ (minimum compression) and the ratio of principal stress differences $\mathbf{R}=(\sigma 2-\sigma 3) /(\sigma 1-\sigma 3)$.

The four parameters are determined by using successively an improved version of the Right Dihedral method of Angelier and Mechler (1977), and a four-dimensional numeric rotational optimisation method (Delvaux, 1993).

\subsection{Quality ranking}

A statistical method designed by Delvaux et al. (1997) is used to determine the reliability of the final stress tensor. The quality ranking is defined as:

$\mathrm{Q}=\mathrm{n}\left(\mathrm{n} / \mathrm{n}_{\mathrm{t}}\right) / \alpha$

The quality rank $\mathrm{Q}$ combines the total number of fault data measured $\left(\mathrm{n}_{t}\right)$, the number of fault data used for the stress tensor determination (n) and the mean slip deviation $(\alpha)$. It ranges from $\mathrm{A}$ (good) to $\mathrm{D}$ (unreliable), with a tensor rank ranging from $>1.5$ to a tensor rank smaller than 0.3 .

\subsection{Stress regime}

The stress regime is determined by the nature of the vertical stress axes: extensional $\left(\sigma 2 \mathrm{~S}_{\mathrm{Hmax}}\right)$ when $\sigma 1$ is vertical, strike-slip $\left(\sigma 1 \mathrm{~S}_{\mathrm{H} \max }\right)$ when $\sigma 2$ is vertical and compressional $\left(\sigma 1 \mathrm{~S}_{\text {Hmax }}\right)$ when $\sigma 3$ is vertical (Delvaux et al., 1997). The type of stress regime can be expressed numerically as defined by Delvaux et al. (1997) by using the stress regime index R' ranging from 0.0 to 3.0 .

The stress regime index R' defines the stress regime completely and is convenient for computing the mean regional stress regime from a series of individual stress tensors in a given area.

\subsection{Age constraints of stress tensors}

The relative age of a stress tensor is estimated from crosscutting relationships of striations and fault planes (fault-slip data) and from the age of particular rock units by constraining these tensors. Also, an age can be indirectly inferred from faulting depth as indicated by mineralization on the fault plane and its consolidation state. Epidote-chlorite minerals can be indicators for deep brittle faulting. Haematite can be formed at less deep levels. Consolidated breccia and fault gauges on the fault surface are used as indicators for older faulting, while non- consolidated breccia and gauge indicate very superficial faulting.

\section{Palaeostress analysis}

The orientation of the stress field was determined by selecting those measurements of mesostructures with a clear sense of movement. Many exposures have been examined but a station was only established at sites with suitable mesostructures. About 89 measurement sites or stations are distributed over the study area. Sites are located on exposures ranging from Neoproterozoic crystalline basement rocks to Miocene sediments. A total of 2773 fault-slip data were measured in different sites.

Three types of mesostructures were commonly measured: minor faults with slip lines (striations), joints and dykes. Striations, mineral steps, stratigraphic separation and displace- 


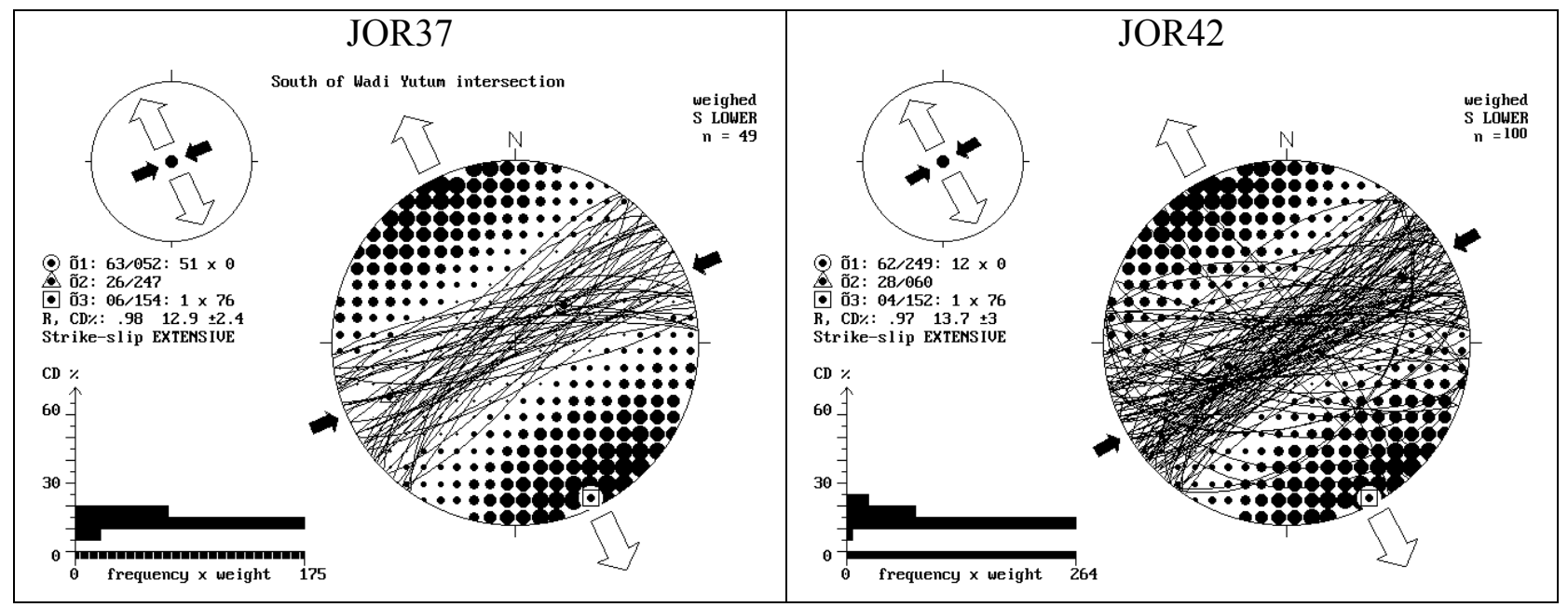

Fig. 2. Stress inversion results for the NE-SW trending dykes.

ment of dykes were used to determine the sense of movement. Some outcrops show very clear indicators, especially the fresh ones like new road-cuts and quarries.

The data yielded 2245 useful values $(81 \%)$ in 88 different tensors, which is a good score. Table 1 shows the number of fault data (n) used for the stress tensor determination; total number of fault data measured in the field $\left(\mathrm{n}_{t}\right)$; plunge and azimuth of the principal stress axes $(\sigma 1, \sigma 2$ and $\sigma 3)$; stress ratio $(\mathrm{R})$; mean slip deviation $(\alpha)$; quality ranking $(\mathrm{Q})$; stress index (R') and the tensor type. Some tensors give no reliable quality (rank D) because of either a large slip deviation $(\alpha)$ or too few faults present to constrain a tensor (n).

The stress inversion results and their correlation allow the definition of seven palaeostress groups (corresponding to stress stages T1-T7). The tensors are grouped according to their similarities as a function of stress axes orientation $\left(\mathrm{S}_{\mathrm{Hmax}}\right)$, stress regime index, stratigraphic relation and fault gauge composition. All obtained stress tensors are listed in Table 1 and displayed on structural maps for each of the palaeostress stage. Some sites exhibit more than one tensor, indicating that more than one movement (stage) occurred. The relative chronology of the palaeostress stages is established where possible crosscutting relationships between the several generations of striations exist.

\subsection{Palaeostress directions}

The palaeostress directions are the following:

T1a: NE-SW $\mathrm{S}_{\text {Hmax }}$, defined from NE-SW Late Neoproterozoic dykes;

T1b: NE-SW $S_{\text {Hmax }}$ transtensional stress regime;

T2a: N-S S $\mathrm{S}_{\mathrm{Hmax}}$, defined from N-S Late Neoproterozoic dykes;

T2b: N-S S $\mathrm{H}_{\max }$ transpressional stress regime (only in Neoproterozoic basement);

T3: $\quad$ E-W $S_{\text {Hmax }}$ strike-slip stress regime;

T4: NW-SE $\mathrm{S}_{\mathrm{Hmax}}$ strike-slip stress regime;

T5: $\quad \mathrm{N}-\mathrm{S} \mathrm{S}_{\mathrm{Hmax}}$ transpressional stress regime;

T6: N-S S $S_{\text {Hmax }}$ extensional stress regime;

T7: $\quad \mathrm{N}-\mathrm{S} \mathrm{S}_{\mathrm{hmin}}$ extensional stress regime;

T8: NW-SE $S_{\text {Hmax }}$ strike-slip stress regime (present-day stress field).

$\mathrm{S}_{\mathrm{Hmax}}$ for each group were determined according to the World Stress Map data base definition.

The palaeostress evolution from T1-T7 corresponds to the formation and reactivation of faults. With each stress field, a generation of new faults was accompanied by reactivated slip on pre-existing planes. Some pre-existing faults are repeatedly reactivated during subsequent deformation. 
Table 1. Palaeostress tensors from fault-slip data (... continues)

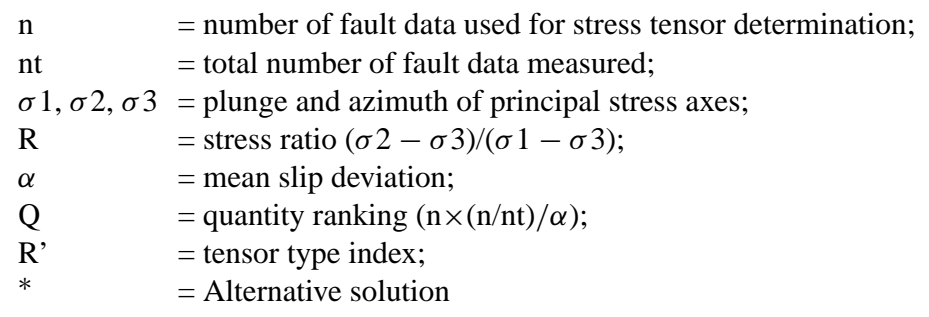

\begin{tabular}{lrccccccccl}
\hline Site & $\mathrm{n}$ & $\mathrm{nt}$ & $\sigma 1$ & $\sigma 2$ & $\sigma 3$ & $\mathrm{R}$ & $\alpha$ & $\mathrm{Q}$ & $\mathrm{R}{ }^{\prime}$ & Type of Tensor \\
\hline \multicolumn{10}{l}{ T1a: NE-SW Late Neoproterozoic dykes } \\
\hline JOR25 & 12 & 16 & $82 / 116$ & $04 / 236$ & $07 / 326$ & 1.0 & 9.5 & $\mathrm{~B}$ & 1.0 & Strike-slip extensive \\
JOR37 & 49 & 60 & $63 / 052$ & $26 / 247$ & $06 / 154$ & 0.98 & 12.9 & $\mathrm{~A}$ & 0.98 & Strike-slip extensive \\
JOR37 & 8 & 10 & $66 / 017$ & $16 / 246$ & $17 / 151$ & 1.0 & 9.6 & $\mathrm{~B}$ & 1.0 & Strike-slip extensive \\
JOR42 & 100 & 122 & $62 / 249$ & $28 / 060$ & $04 / 152$ & 0.97 & 13.7 & $\mathrm{~A}$ & 0.97 & Strike-slip extensive \\
\hline Mean:4 & 169 & 208 & $83 / 017$ & $05 / 242$ & $05 / 152$ & 0.99 & & & 0.99 & Strike-slip extensive \\
\hline
\end{tabular}

T2a: N-S Late Neoproterozoic dykes

\begin{tabular}{|c|c|c|c|c|c|c|c|c|c|c|}
\hline JOR42 & 19 & 26 & 70/014 & $20 / 193$ & $00 / 283$ & 1.0 & 9.4 & A & 1.0 & Strike-slip extensive \\
\hline \multicolumn{11}{|c|}{ T1b: NE-SW S Smax (Late Neoproterozoic) } \\
\hline JOR12 & 12 & 111 & $62 / 357$ & $26 / 203$ & $11 / 107$ & 0.87 & 8.49 & $\mathrm{D}$ & 0.87 & Strike-slip extensive \\
\hline JOR17 & 14 & 50 & $58 / 341$ & $06 / 241$ & $31 / 148$ & 0.49 & 8.58 & $\mathrm{~B}$ & 0.49 & Pure extensive \\
\hline JOR19 & 13 & 86 & $05 / 227$ & $68 / 330$ & $21 / 134$ & 0.39 & 9.68 & $\mathrm{D}$ & 1.61 & Pure strike-slip \\
\hline JOR28 & 13 & 68 & $26 / 047$ & $61 / 257$ & $13 / 143$ & 0.71 & 6.58 & $\mathrm{C}$ & 1.29 & Extensive strike-slip \\
\hline JOR33 & 23 & 65 & $37 / 060$ & $53 / 228$ & $06 / 325$ & 0.78 & 11.14 & $\mathrm{~B}$ & 1.22 & Extensive strike-slip \\
\hline JOR33A & 16 & 86 & $39 / 037$ & $50 / 227$ & $06 / 131$ & 0.34 & 10.51 & $\mathrm{D}$ & 1.66 & Pure strike-slip \\
\hline JOR35 & 16 & 106 & $54 / 226$ & $36 / 049$ & $01 / 318$ & 0.69 & 13.54 & $\mathrm{D}$ & 0.69 & Pure extensive \\
\hline JOR36 & 23 & 35 & $61 / 276$ & $20 / 047$ & $20 / 144$ & 0.79 & 9.2 & A & 0.79 & Strike-slip extensive \\
\hline JOR36C & 14 & 68 & $52 / 258$ & $37 / 065$ & $06 / 160$ & 0.59 & 10.03 & $\mathrm{D}$ & 0.59 & Pure extensive \\
\hline JOR38 & 36 & 98 & $82 / 209$ & 07/068 & $06 / 338$ & 0.93 & 9.51 & B & 0.93 & Strike-slip extensive \\
\hline JOR39 & 10 & 35 & $10 / 062$ & $30 / 326$ & $58 / 168$ & 0.19 & 11.93 & $\mathrm{D}$ & 2.19 & Strike-slip compressive \\
\hline JOR40A & 33 & 136 & $15 / 242$ & $75 / 069$ & $02 / 332$ & 0.29 & 8.45 & B & 1.71 & Compressive strike-slip \\
\hline JOR45 & 25 & 46 & $19 / 220$ & $70 / 043$ & $02 / 310$ & 0.09 & 10.07 & B & 1.91 & Compressive strike-slip \\
\hline JOR48 & 14 & 74 & $68 / 258$ & $21 / 059$ & $06 / 152$ & 0.37 & 4.0 & B & 0.37 & Pure extensive \\
\hline JOR49 & 23 & 46 & $38 / 248$ & $51 / 057$ & $06 / 154$ & 0.57 & 12.66 & $\mathrm{~B}$ & 1.43 & Pure strike-slip \\
\hline Mean:15 & 285 & 1110 & $09 / 053$ & $80 / 262$ & $05 / 144$ & 0.82 & & & 1.18 & Extensive strike-slip \\
\hline \multicolumn{11}{|c|}{ T2b: N-S S Hmax $_{\text {(Late Neoproterozoic) }}$} \\
\hline JOR12* & 38 & 96 & $01 / 342$ & $86 / 238$ & 03/072 & 0.42 & 8.46 & A & 1.58 & Pure strike-slip \\
\hline JOR17 & 30 & 50 & 03/171 & 24/079 & $66 / 267$ & 0.38 & 8.73 & A & 2.38 & Pure compressive \\
\hline JOR19* & 34 & 86 & 09/003 & $62 / 256$ & 26/097 & 0.24 & 10.33 & $\mathrm{~B}$ & 1.76 & Compressive strike-slip \\
\hline Mean:3 & 102 & 232 & $02 / 352$ & $72 / 256$ & $18 / 083$ & 0.09 & & & 1.91 & Compressive strike-slip \\
\hline
\end{tabular}

\subsubsection{T1a: NE-SW Late Neoproterozoic dykes}

The NE-SW trending dykes in the Neoproterozoic crystalline basement rocks represent the oldest intrusion phase in the study area. They have a minimum age of $570 \mathrm{Ma}$. These dykes have been used to calculate the stress tensor.

The calculated results are listed in Table 1. Four stress tensors have been obtained with 169 measured data using the assumption that dykes are parallel to $\sigma 1$ and $\sigma 2$ and perpendicular to $\sigma 3$. All the stress tensors have sub-vertical $\sigma 1$-axes and sub-horizontal $\sigma 2$ - and $\sigma 3$-axes. The mean orientations of the principal stress axes are $\sigma 1$ at $83 / 017, \sigma 2$ at $05 / 242$ and $\sigma 3$ at $05 / 152$. The stress ratio $\mathrm{R}$ is 0.99 indicating a strike-slip extensive regime (transtensive).

Figure 2 shows plots for some examples of the stress tensors and illustrates the subset of the data together with the orientation of the calculated principal stress axes. The results indicate a clear extensional regime ( $\sigma 1$ is vertical while $\sigma 2$ and $\sigma 3$ are horizontal) with a NE-SW maximum principal stress axis $\mathrm{S}_{\mathrm{Hmax}}(\sigma 2)$ and a NW-SE minimum principal axis $\mathrm{S}_{\mathrm{hmin}}(\sigma 3)$. 
Table 1. ... continued

\begin{tabular}{|c|c|c|c|c|c|c|c|c|c|c|}
\hline Site & $\mathrm{n}$ & $\mathrm{nt}$ & $\sigma 1$ & $\sigma 2$ & $\sigma 3$ & $\mathrm{R}$ & $\alpha$ & Q & $\mathrm{R}^{\prime}$ & Type of Tensor \\
\hline \multicolumn{11}{|c|}{$\begin{array}{l}\text { T3: E-W S Smax (affects Neoproterozoic, Cambrian, Ordovician and Cretaceous but not younger rocks) } \\
\text { [Syrian Arc Stress Field, SAS] }\end{array}$} \\
\hline JOR10 & 14 & 116 & $09 / 259$ & $69 / 012$ & $19 / 166$ & 0.22 & 7.86 & $\mathrm{D}$ & 1.78 & Compressive strike-slip \\
\hline JOR23 & 12 & 35 & $11 / 252$ & $64 / 006$ & $23 / 157$ & 0.32 & 8.77 & $\mathrm{C}$ & 1.68 & Pure strike-slip \\
\hline JOR25B & 35 & 58 & $25 / 073$ & $23 / 332$ & $55 / 205$ & 0.58 & 8.28 & A & 2.58 & Pure compressive \\
\hline JOR25C & 29 & 43 & $09 / 273$ & $63 / 021$ & $25 / 179$ & 0.0 & 13.31 & $\mathrm{~B}$ & 2.0 & Pure strike-slip \\
\hline JOR25D & 9 & 34 & $11 / 256$ & $77 / 108$ & $07 / 347$ & 0.44 & 9.02 & $\mathrm{D}$ & 1.56 & Pure strike-slip \\
\hline JOR28 & 12 & 68 & $07 / 283$ & $61 / 181$ & $28 / 017$ & 0.92 & 5.98 & $\mathrm{C}$ & 1.08 & Extensive strike-slip \\
\hline JOR29 & 23 & 37 & $68 / 299$ & $20 / 091$ & $10 / 184$ & 0.77 & 5.92 & $\mathrm{~A}$ & 0.77 & Strike-slip extensive \\
\hline JOR33A & 9 & 86 & $26 / 273$ & $13 / 177$ & $61 / 062$ & 0.51 & 10.83 & $\mathrm{D}$ & 2.51 & Pure compressive \\
\hline JOR34 & 19 & 251 & $14 / 289$ & $67 / 162$ & $17 / 024$ & 0.66 & 16.75 & $\mathrm{D}$ & 1.34 & Pure strike-slip \\
\hline JOR35 & 51 & 106 & $01 / 273$ & $60 / 005$ & $29 / 183$ & 0.29 & 12.52 & $\mathrm{~A}$ & 1.71 & Compressive strike-slip \\
\hline JOR37B & 18 & 67 & $18 / 260$ & $63 / 030$ & $19 / 164$ & 0.52 & 11.53 & $\mathrm{C}$ & 1.48 & Pure strike-slip \\
\hline JOR40A & 15 & 136 & $52 / 139$ & $22 / 261$ & $29 / 003$ & 0.44 & 12.59 & $\mathrm{D}$ & 0.44 & Pure extensive \\
\hline JOR47 & 37 & 44 & $84 / 261$ & $06 / 101$ & 02/011 & 0.47 & 14.78 & A & 0.47 & Pure extensive \\
\hline JOR48 & 24 & 74 & $00 / 108$ & $64 / 018$ & $26 / 199$ & 0.32 & 11.66 & $\mathrm{~B}$ & 1.68 & Pure strike-slip \\
\hline JOR52 & 17 & 106 & $01 / 103$ & $76 / 197$ & $14 / 012$ & 0.44 & 13.42 & $\mathrm{D}$ & 1.56 & Pure-strike-slip \\
\hline Mean:15 & 324 & 1261 & $05 / 271$ & $84 / 060$ & $03 / 181$ & 0.49 & & & 1.51 & Pure strike-slip \\
\hline
\end{tabular}

T4: NW-SE $S_{\text {Hmax }}$ (affected Neoproterozoic, Cambrian, Ordovician, Cretaceous and Palaeocene/Eocene but not younger rocks) [Dead Sea Stress Field, DSS]

\begin{tabular}{lrrllllllll}
\hline JOR17 & 11 & 11 & $09 / 307$ & $57 / 050$ & $32 / 211$ & 0.64 & 4.34 & $\mathrm{~A}$ & 1.36 & Pure strike-slip \\
JOR08 & 43 & 71 & $74 / 097$ & $08 / 337$ & $13 / 245$ & 0.6 & 7.42 & $\mathrm{~A}$ & 0.6 & Pure extensive \\
JOR09 & 33 & 49 & $09 / 319$ & $67 / 207$ & $21 / 053$ & 0.17 & 13.21 & $\mathrm{~A}$ & 1.83 & Compressive strike-slip \\
JOR10 & 48 & 116 & $04 / 319$ & $80 / 203$ & $10 / 049$ & 0.8 & 8.89 & $\mathrm{~A}$ & 1.2 & Extensive strike-slip \\
JOR11 & 19 & 54 & $51 / 128$ & $37 / 329$ & $10 / 231$ & 0.64 & 6.02 & $\mathrm{~B}$ & 0.64 & Pure extensive \\
JOR12 & 15 & 111 & $06 / 133$ & $83 / 319$ & $01 / 223$ & 0.69 & 8.75 & $\mathrm{D}$ & 1.31 & Pure strike-slip \\
JOR14 & 11 & 48 & $01 / 129$ & $67 / 221$ & $23 / 039$ & 0.27 & 5.66 & $\mathrm{C}$ & 1.73 & Compressive strike-slip \\
JOR15 & 21 & 35 & $15 / 300$ & $63 / 180$ & $22 / 037$ & 0.83 & 11.4 & $\mathrm{~B}$ & 1.17 & Extensive strike-slip \\
JOR16 & 32 & 45 & $09 / 327$ & $81 / 157$ & $01 / 057$ & 0.32 & 10.11 & $\mathrm{~A}$ & 1.68 & Pure extensive \\
JOR25B & 8 & 58 & $70 / 046$ & $04 / 307$ & $19 / 215$ & 0.64 & 2.97 & $\mathrm{C}$ & 0.64 & Pure extensive \\
JOR33 & 26 & 65 & $14 / 158$ & $72 / 296$ & $12 / 065$ & 0.77 & 12.31 & $\mathrm{~B}$ & 1.23 & Extensive strike-slip \\
JOR33A & 40 & 86 & $05 / 332$ & $84 / 181$ & $02 / 062$ & 0.27 & 8.74 & $\mathrm{~A}$ & 1.73 & Compressive strike-slip \\
JOR34 & 23 & 251 & $52 / 289$ & $34 / 137$ & $14 / 037$ & 0.78 & 11.48 & $\mathrm{D}$ & 0.78 & Strike-slip extensive \\
JOR34 & 56 & 251 & $05 / 336$ & $72 / 081$ & $17 / 245$ & 0.67 & 11.79 & $\mathrm{~B}$ & 1.33 & Pure strike-slip \\
JOR35 & 24 & 106 & $04 / 334$ & $63 / 237$ & $27 / 066$ & 0.25 & 12.58 & $\mathrm{C}$ & 1.75 & Compressive strike-slip \\
JOR36C & 11 & 68 & $07 / 304$ & $82 / 095$ & $04 / 214$ & 0.45 & 7.28 & $\mathrm{D}$ & 1.55 & Pure strike-slip \\
JOR38 & 41 & 98 & $05 / 143$ & $80 / 260$ & $08 / 052$ & 0.55 & 10.71 & $\mathrm{~A}$ & 1.45 & Pure strike-slip \\
JOR45 & 19 & 46 & $11 / 326$ & $62 / 078$ & $26 / 231$ & 0.84 & 16.24 & $\mathrm{C}$ & 1.16 & Extensive strike-slip \\
JOR48 & 22 & 74 & $02 / 149$ & $81 / 246$ & $09 / 058$ & 0.14 & 4.66 & $\mathrm{~B}$ & 1.86 & Compressive strike-slip \\
JOR55 & 26 & 37 & $28 / 321$ & $56 / 103$ & $18 / 221$ & 0.72 & 11.09 & $\mathrm{~A}$ & 1.28 & Extensive strike-slip \\
\hline Mean:20 & 529 & 1429 & $05 / 321$ & $85 / 151$ & $01 / 051$ & 0.69 & & & 1.31 & Pure strike-slip \\
\hline
\end{tabular}

\subsubsection{T1b: NE-SW S $\mathrm{H}_{\max }$ (Late Neoproterozoic)}

The oldest structures recorded in the Neoproterozoic crystalline basement rocks point to NE-SW directed compression. The palaeostress of this stage represents 15 tensors with 285 fault-slip data. The results of these tensors obtained from different sites that constrain this stage are given in Table 1.

The palaeostress tensors define a strike-slip regime with a well-constrained $\sigma$ 1-orientation $\left(\mathrm{S}_{\mathrm{H} \max }\right.$ ) to the NE. Some tensors indicate compressive and extensive regimes. This means that, although the same orientations for the three principal stress axes are present, the relative magnitudes of the axes are in different order (in this case the $\sigma 1-, \sigma 2$ - and $\sigma 3$ axes are swapped).

All tensors of this group were observed only in the Neoproterozoic crystalline basement rocks. Faults were generally associated with chlorite-epidote mineralizations.

The mean orientations of the principal stress axes are $\sigma 1$ at $09 / 053, \sigma 2$ at $80 / 262$ and $\sigma 3$ at $05 / 144$. The stress regime index for the mean weighed tensor is 1.18 , which indicates an extensive strike-slip regime (transtensive). Fig. 3 shows example of this group which indicate that the sinistral displacement along E-W to ENE-WSW directed faults and the dextral displacement along N-S to NNE-SSW directed faults, 
Table 1. ... continued

\begin{tabular}{|c|c|c|c|c|c|c|c|c|c|c|}
\hline Site & $\mathrm{n}$ & $\mathrm{nt}$ & $\sigma 1$ & $\sigma 2$ & $\sigma 3$ & $\mathrm{R}$ & $\alpha$ & Q & $\mathrm{R}^{\prime}$ & Type of Tensor \\
\hline \multicolumn{11}{|c|}{$\begin{array}{l}\text { T5: N-S S } \mathrm{Hmax}_{\text {max }} \text { strike-slip to compressional stress regime (affects Neoproterozoic, Cambrian, Ordovician, } \\
\text { Cretaceous, Palaeocene/Eocene and Miocene (Dana Conglomerates)) [Dead Sea Stress Field, DSS] }\end{array}$} \\
\hline JOR08 & 24 & 71 & $31 / 020$ & $16 / 280$ & $54 / 166$ & 0.68 & 9.92 & $\mathrm{~B}$ & 2.68 & Pure compression \\
\hline JOR10 & 35 & 116 & $05 / 185$ & $80 / 304$ & 08/094 & 0.64 & 6.62 & $\mathrm{~A}$ & 1.36 & Pure strike-slip \\
\hline JOR12 & 74 & 111 & 07/009 & $80 / 236$ & 08/100 & 0.21 & 10.7 & A & 1.79 & Compressive strike-slip \\
\hline JOR14 & 34 & 48 & 18/008 & $66 / 229$ & $14 / 103$ & 0.86 & 6.94 & A & 1.14 & Extensive strike-slip \\
\hline JOR15 & 7 & 35 & $33 / 185$ & $56 / 023$ & $08 / 280$ & 0.84 & 14.18 & $\mathrm{D}$ & 1.16 & Extensive strike-slip \\
\hline JOR19 & 48 & 86 & $05 / 352$ & $65 / 253$ & $25 / 085$ & 0.25 & 9.66 & A & 1.75 & Compressive strike-slip \\
\hline JOR20 & 22 & 39 & 07/001 & $76 / 2$ & $12 / 093$ & & 2.58 & A & 1.2 & Extensive strike-slip \\
\hline JOR25A & 23 & 39 & $11 / 359$ & $01 / 26$ & $79 / 174$ & 0.38 & 12.72 & $\mathrm{~B}$ & 2.38 & Pure compressive \\
\hline JOR25D & 19 & 34 & $26 / 201$ & $50 / 0$ & $29 / 307$ & 0.22 & 6.02 & A & 1.78 & Compressive strike-slip \\
\hline JOR28 & 38 & 68 & $04 / 170$ & & $25 / 079$ & 0.17 & & $\mathrm{~B}$ & & \\
\hline JOR36C & 30 & 68 & $06 / 352$ & $74 / 241$ & $14 / 083$ & 0.21 & 12.95 & $\mathrm{~B}$ & 1.79 & Compressive strike-slip \\
\hline JOR37B & 32 & 67 & & & 05/078 & 0.34 & & B & & \\
\hline JOR39 & 16 & 35 & $00 / 3$ & $67 / 0$ & $23 / 2$ & 0.38 & 12 . & $\mathrm{B}$ & 1. & Pure strike-slip \\
\hline & 57 & 136 & & & $02 / 0$ & & 11. & A & & Compressive strike \\
\hline JOR51B & 7 & 22 & $21 / 167$ & $12 / 262$ & $65 / 020$ & 0.52 & 7.3 & $\mathrm{C}$ & 2.52 & \\
\hline JOR52 & 20 & 106 & & & $58 / 002$ & & & $\mathrm{D}$ & & mpressive \\
\hline Mean:16 & 486 & 1081 & $02 / 179$ & $88 / 334$ & $01 / 089$ & 0.21 & & & 1.79 & strike-slip \\
\hline \multicolumn{11}{|c|}{ T6: N-S S $\mathrm{Hmax}_{\text {max }}$ extensional stress regime (affects all rocks units in the study area) } \\
\hline JOR23 & 15 & 35 & $76 / 112$ & $04 / 006$ & $14 / 276$ & 0.76 & 8.98 & $\mathrm{~B}$ & 0.76 & \\
\hline & 18 & 251 & & & & & & $\mathrm{D}$ & & \\
\hline & 75 & 251 & $66 / 061$ & $16 / 191$ & $18 / 286$ & 0.16 & 11.47 & $\mathrm{~A}$ & 0.1 & Radial extensive \\
\hline & 47 & 94 & $87 / 241$ & $01 / 352$ & 03/082 & & & A & 0.8 & Strike-slip extensive \\
\hline JOR50 & 11 & 94 & $57 / 018$ & $22 / 145$ & $24 / 246$ & 0.28 & 8.37 & $\mathrm{D}$ & 0.28 & Pure \\
\hline Mean:5 & 166 & 725 & $78 / 050$ & $07 / 177$ & $09 / 268$ & 0.51 & & & 0.51 & \\
\hline \multicolumn{11}{|c|}{ T7: N-S $S_{\mathrm{hmin}}$ extensional stress regime (affects all rocks units in the study area) } \\
\hline JOR11 & 20 & 54 & $58 / 320$ & $03 / 053$ & $32 / 145$ & 0.21 & 10.36 & $\mathrm{~B}$ & 0.21 & \\
\hline JOR36B & 12 & 17 & $71 / 239$ & $17 / 089$ & $08 / 356$ & & 10.3 & $\mathrm{C}$ & 0.28 & \\
\hline JOR46 & 6 & 37 & $56 / 191$ & & $32 / 033$ & & 0.5 & A & 0.59 & \\
\hline JOR50 & 31 & 94 & $84 / 163$ & $03 / 281$ & 05/012 & 0.25 & 7.59 & $\mathrm{~B}$ & 0.25 & Pure ex \\
\hline Mean:4 & 69 & 202 & $86 / 207$ & $02 / 090$ & $04 / 360$ & 0.33 & & & 0.33 & Pure extensive \\
\hline \multicolumn{11}{|c|}{ Alternativ solution for JOR10, JOR12 and JOR19 } \\
\hline JOR10 & 41 & 116 & $19 / 043$ & $71 / 229$ & $02 / 133$ & 0.28 & 11.02 & $\mathrm{~B}$ & 1.72 & Compressive strike-slip \\
\hline JOR10 & 20 & 116 & $61 / 322$ & $23 / 103$ & $16 / 200$ & 0.44 & 10.81 & $\mathrm{C}$ & 0.44 & Pure extensive \\
\hline JOR10 & 46 & 116 & $06 / 323$ & $79 / 205$ & $10 / 054$ & 0.81 & 10.72 & $\mathrm{~A}$ & 1.19 & Extensive strike-slip \\
\hline JOR12 & 38 & 96 & $01 / 342$ & $86 / 238$ & 03/072 & 0.42 & 8.46 & $\mathrm{~A}$ & 1.58 & Pure strike-slip \\
\hline JOR12 & 33 & 96 & $15 / 015$ & $65 / 250$ & $20 / 110$ & 0.27 & 7.18 & A & 1.73 & Compressive strike-slip \\
\hline JOR12 & 17 & 96 & 05/021 & $78 / 268$ & $11 / 112$ & 0.97 & 6.98 & $\mathrm{C}$ & 1.03 & Extensive strike-slip \\
\hline JOR19 & 34 & 86 & 09/003 & $62 / 256$ & 26/097 & 0.24 & 10.33 & $\mathrm{~B}$ & 1.76 & Compressive strike-slip \\
\hline JOR19 & 9 & 86 & $20 / 271$ & $15 / 175$ & $65 / 052$ & 0.28 & 12.32 & $\mathrm{D}$ & 2.28 & Pure compressive \\
\hline JOR19 & 26 & 86 & $18 / 148$ & $72 / 343$ & $05 / 240$ & 0.87 & 10.58 & $\mathrm{~B}$ & 1.13 & Extensive strike-slip \\
\hline
\end{tabular}

are the major components for the expression of this regime in the study area.

\subsubsection{T2a: NNE-SSW to N-S Late Neoproterozoic dykes}

In addition to the NE-SW trending dykes, NNE-SSW to N$\mathrm{S}$ trending dykes were also observed in the Neoproterozoic crystalline basement rocks. Field evidence shows that these are younger than the previous set. The N-S trending dykes have a maximum age of $560 \mathrm{Ma}$.
Due to the limited amount of measurements, only one tensor has been obtained with 19 measured data. The results are listed in Table 1. This tensor has a sub-vertical $\sigma 1$-axis at 70/014 and sub-horizontal $\sigma 2$ - and $\sigma 3$-axes at 20/193 and 00/283 respectively (Fig. 4 ). The data indicate a transtensive stress regime with a N-S maximum principal stress axis $(\sigma 2)$ and an E-W minimum principal stress axis $(\sigma 3)$. 


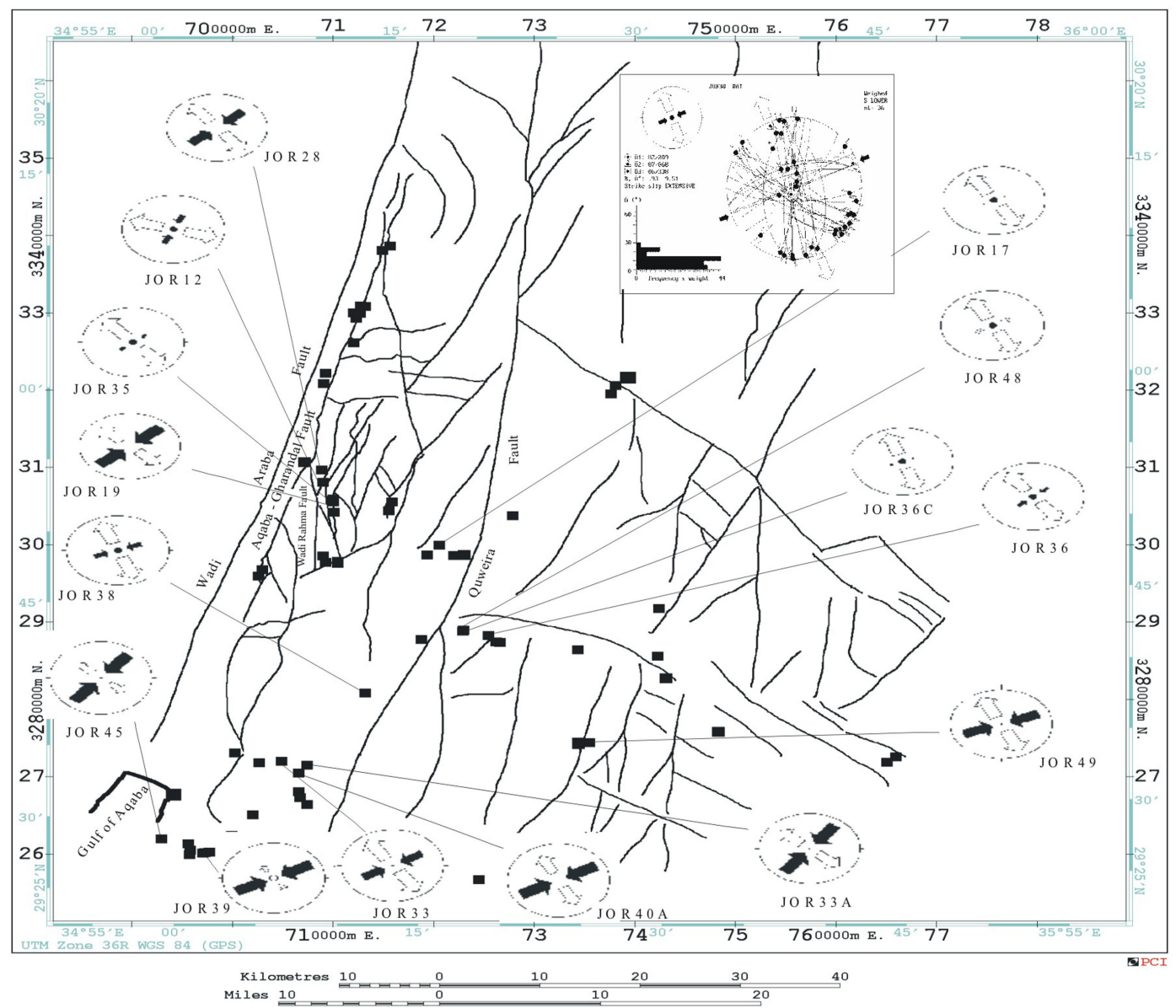

Fig. 3. Structural map with palaeostress tensor group T1b. Inset: one example of stress inversion results for this group.

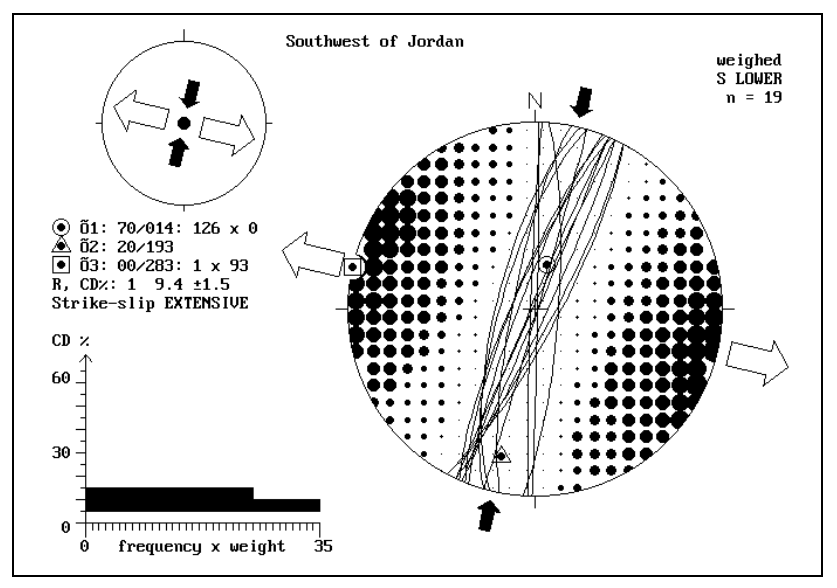

Fig. 4. Stress inversion method for the NNE-SSW to N-S trending dykes.

\subsubsection{T2b: N-S S $\mathrm{S}_{\max }$ (Late Neoproterozoic)}

The second tensor group defines N-S $\mathrm{S}_{\mathrm{Hmax}}$ and represents three tensors with 102 fault-slip data. This group was constructed from the chlorite/epidote rich fault planes observed in the Neoproterozoic crystalline basement rocks. The calculated results of these tensors are listed in Table 1. This stage is characterised by a transpressive stress regime with a well constrained $\sigma 1$ at $02 / 352$ and $\sigma 3$ at 18/083. The three tensors are shown in Fig. 5.

One of the tensors indicates a compressive regime and the other two tensors indicate a strike-slip regime. This means that the relative magnitudes of the stress axes are in different order (in this case the $\sigma 2$ - and $\sigma 3$-axes are swapped). The stress regime created mainly a sinistral strike-slip movement along NE-SW faults and reverse (thrust) movement along EW faults. The Dead Sea Stress field (DSS) will reactivate these faults during Late Cainozoic times.

\subsubsection{T3: E-W S $\mathrm{S}_{\mathrm{Hmax}}$}

The tensors for this direction were obtained from the faultslip data observed in the Neoproterozoic crystalline basement rocks and in Cambrian, Ordovician and Cretaceous rocks (but not in younger ones). The calculated results show 15 tensors obtained on 324 fault-slip data and are listed in Table 1. The example given in Fig. 6 shows that sinistral movement along NW-SE trending faults and dextral movements 


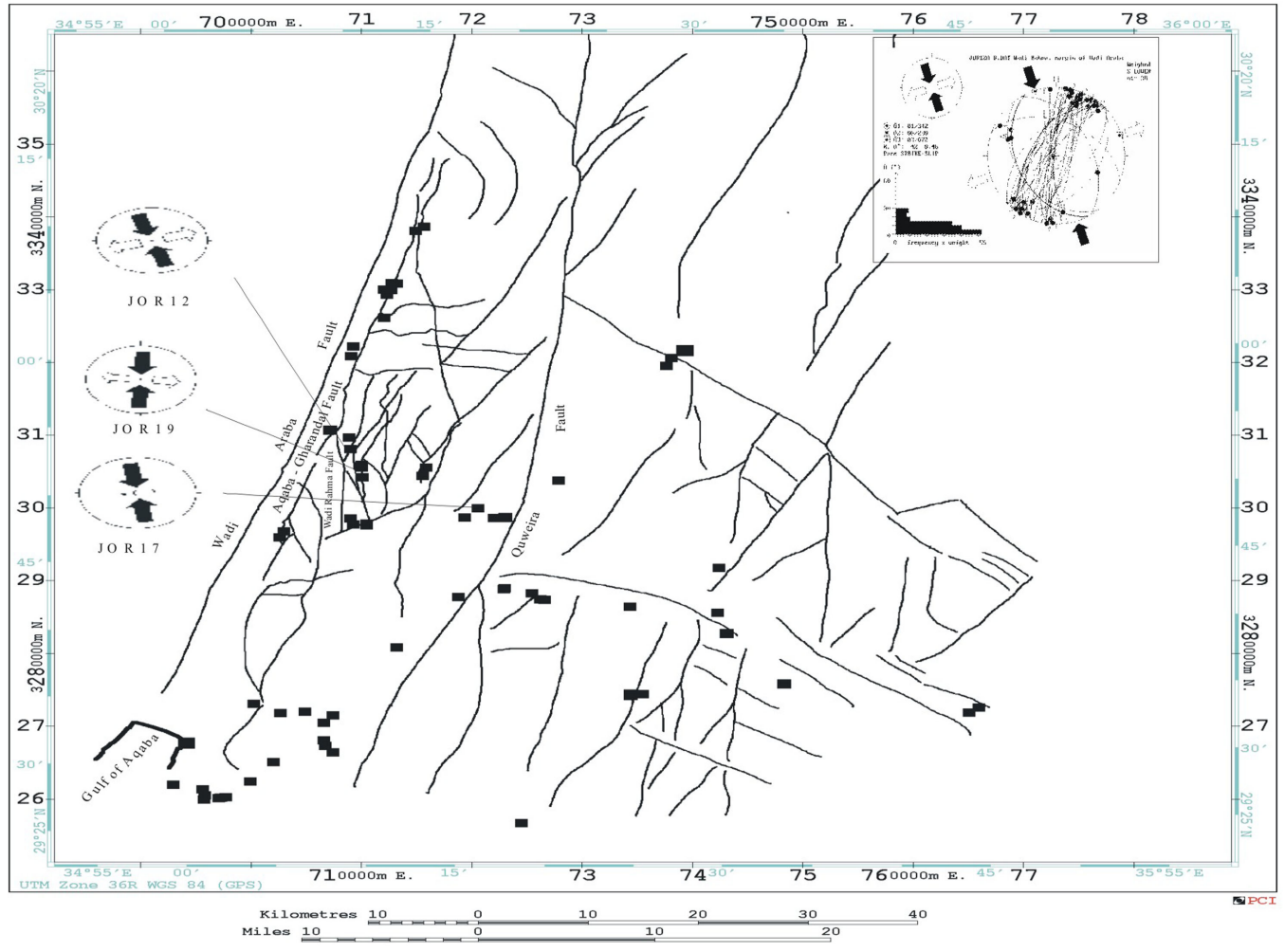

Fig. 5. Structural map with paleostress tensor group T2b. Inset: one example of stress inversion results for this group.

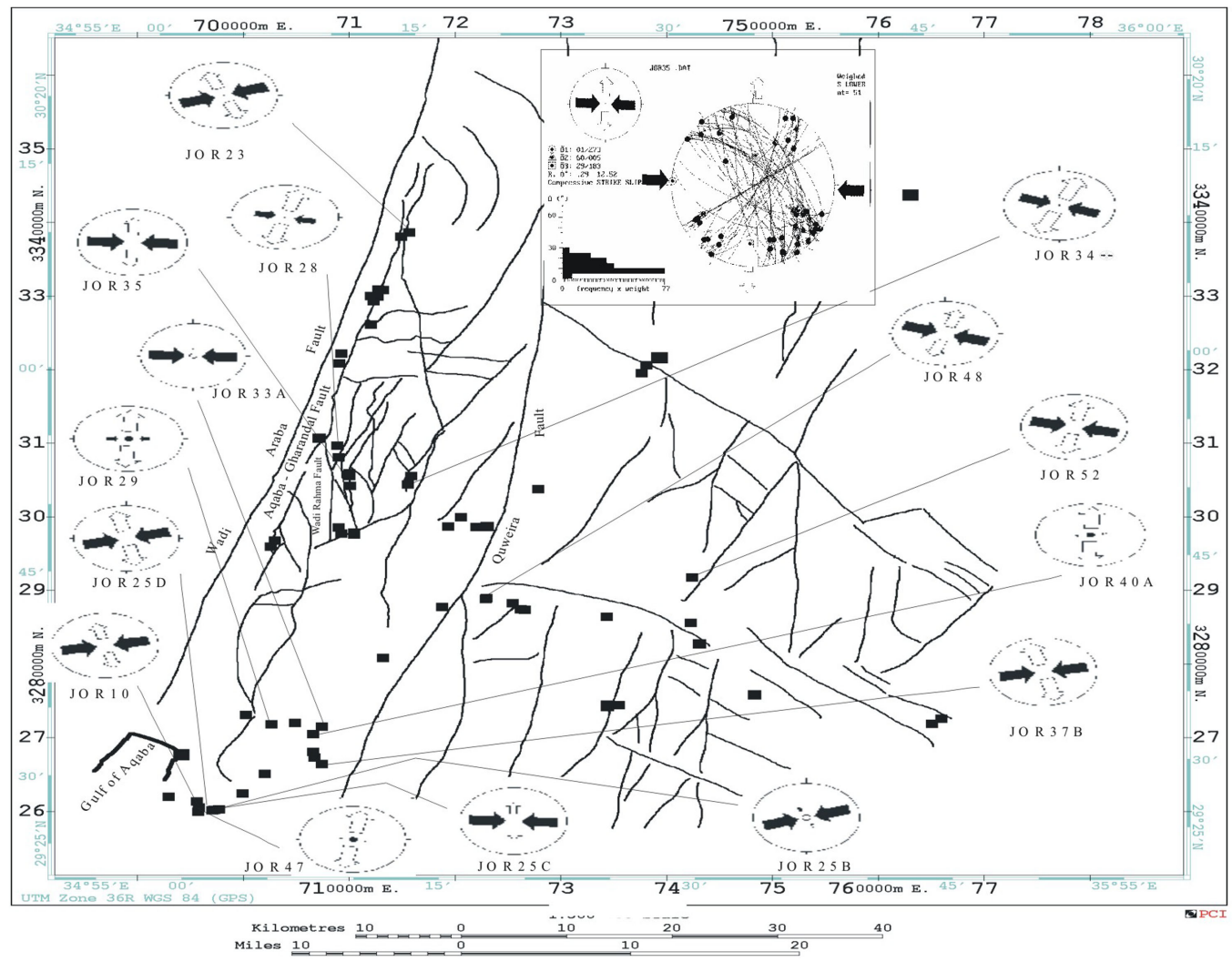

Fig. 6. Structural map with paleostress tensor group T3. Inset: one example of stress inversion results for this group. 


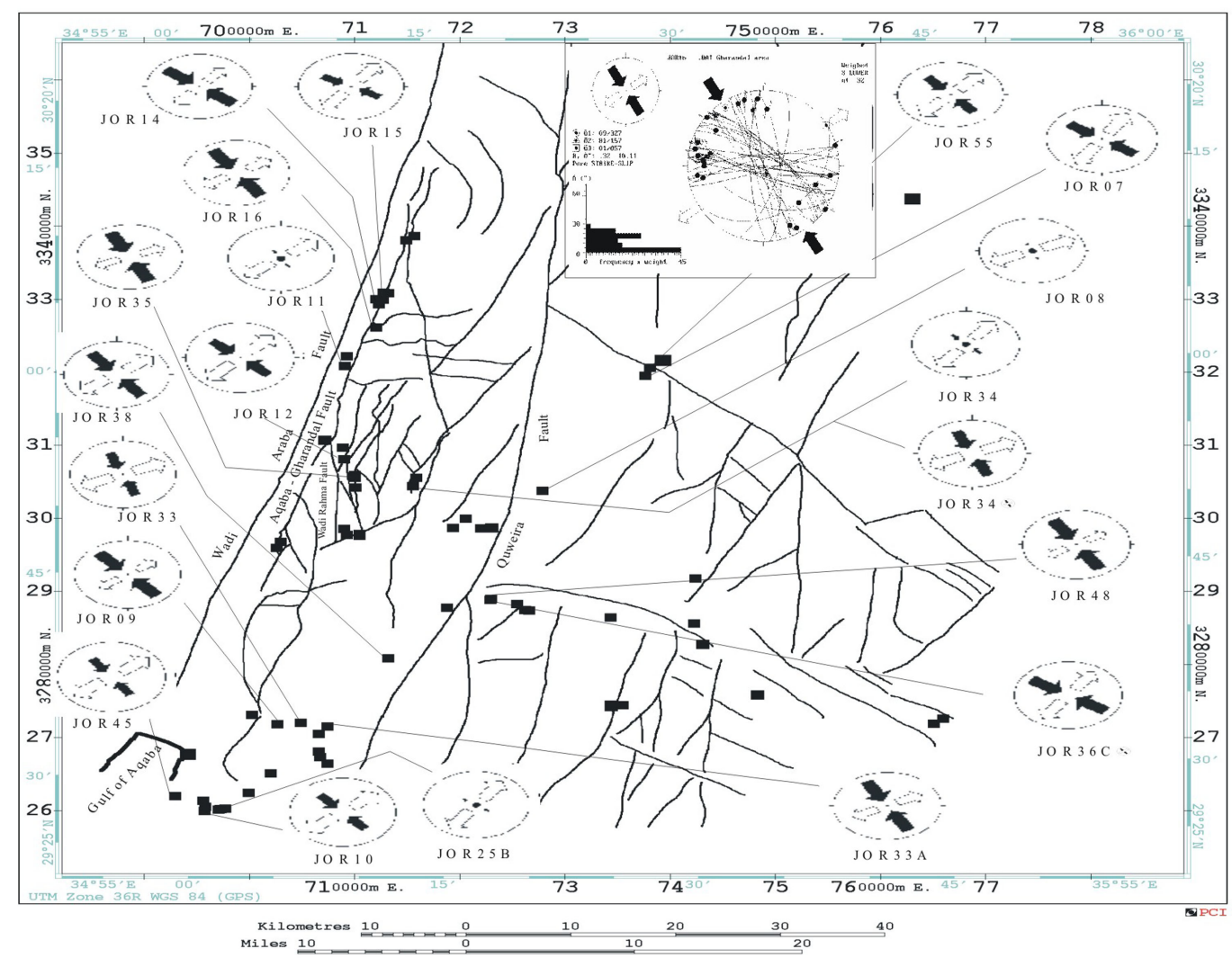

Fig. 7. Structural map with paleostress tensor group T4. Inset: one example for this group.

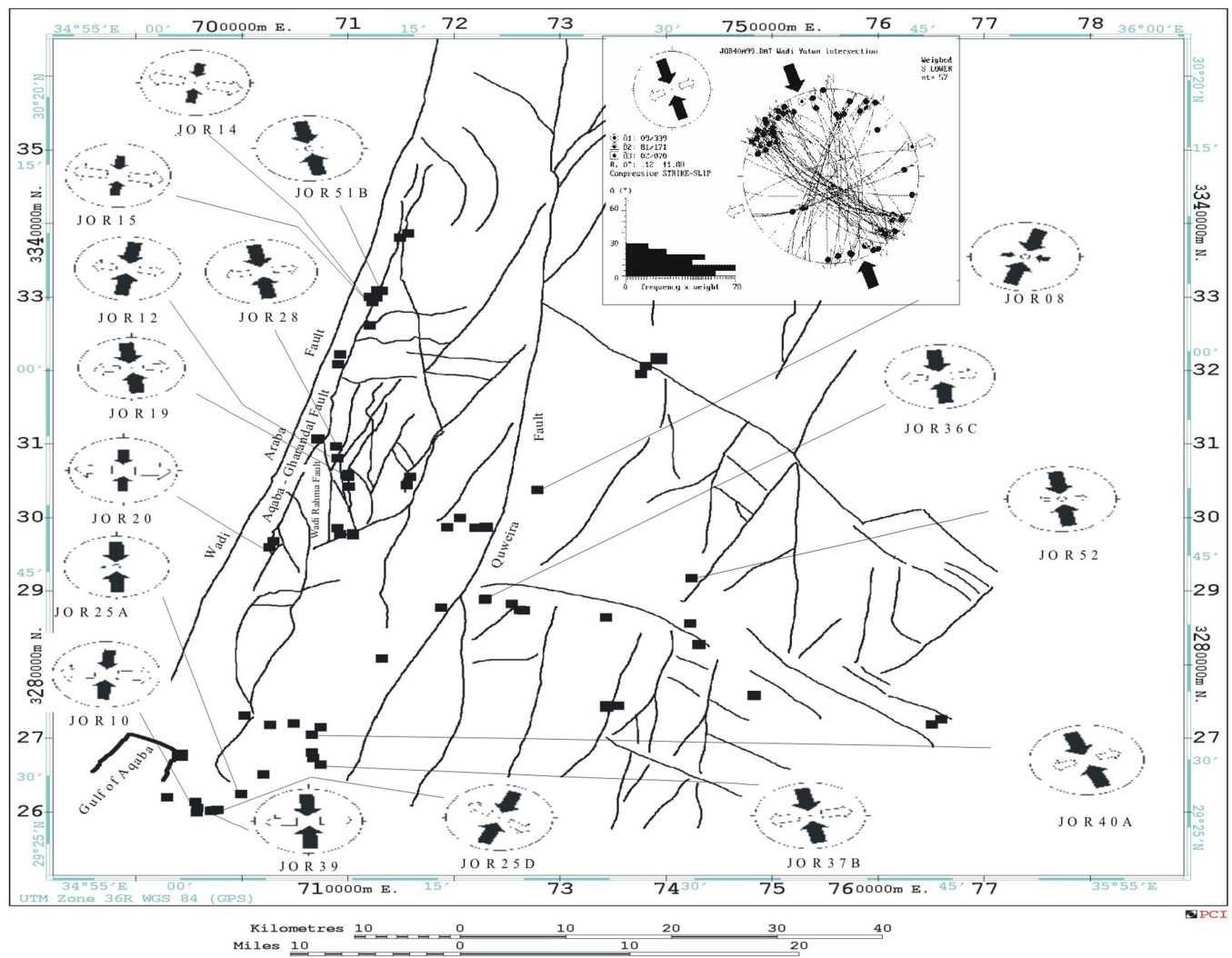

Fig. 8. Structural map with paleostress tensor group T5. Inset: one example for this group. 


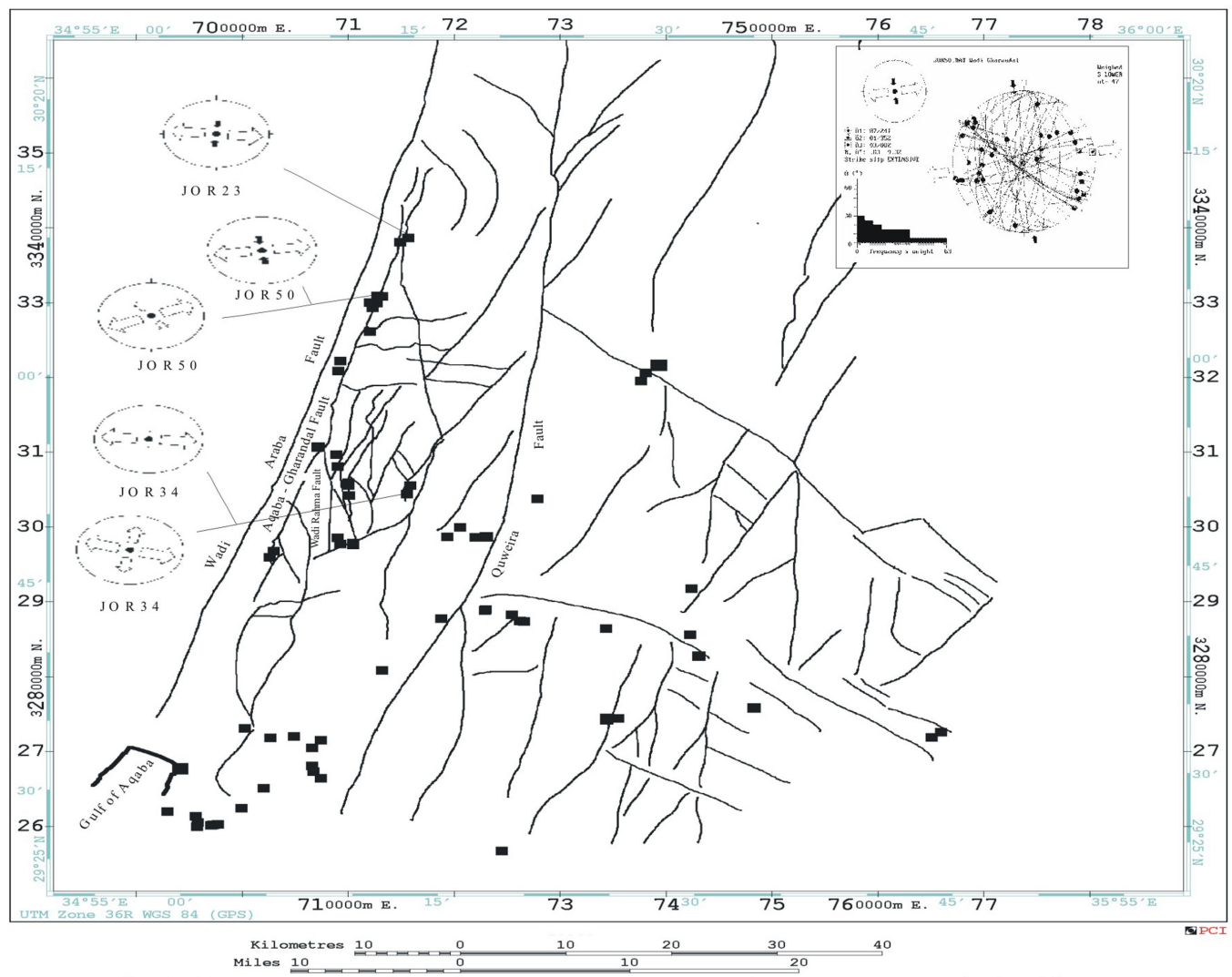

Fig. 9. Structural map with paleostress tensor group T6. Inset: one example for this group.

along NE-SW trending faults are the major components for this stage.

This stage is characterised mainly by a strike-slip regime and by alternation between compressive and extensive regimes with the same orientation of the three principal stress axes but in different order. Evidence of strike-slip faulting of flower structures has been observed south-east of Aqaba. The principal compression axis $(\sigma 1)$ is horizontal with an E-W orientation (05/271), and the principal extension axis $(\sigma 3)$ is also horizontal with a N-S orientation (03/181). The stress regime created NW-SE sinistral faults and reactivated NE-SW dextral faults.

\subsubsection{T4: NW-SE $\mathrm{S}_{\mathrm{Hmax}}$}

This direction was obtained from data observed in the Neoproterozoic crystalline basement and the Cambrian, Ordovician, Cretaceous and Palaeocene/Eocene rocks. The tensors of this stage were not observed in rocks younger than the Palaeocene/Eocene rocks in the study area. Twenty tensors with 529 fault-slip data were obtained in different sites distributed in the study area and shown in Table 1. The calculated results indicate that $\sigma 1\left(\mathrm{~S}_{\mathrm{Hmax}}\right)$ and $\sigma 3\left(\mathrm{~S}_{\mathrm{hmin}}\right)$ are generally sub-horizontal and $\sigma 2$ is sub-vertical. The main orientations of the principal stress axes are $\sigma 1$ at $05 / 321, \sigma 2$ at $85 / 151$ and $\sigma 3$ at $01 / 051$ while the stress index is 1.31 .
The tensors of this stage indicate a strike-slip regime. An example for this stage is shown in Fig. 7.

Four tensors out of twenty indicate extensive regimes (Table 1). This means that, although the same orientations for the principal stress axes are present, the relative magnitudes of the axes vary (in this case the $\sigma 1$ and $\sigma 2$ are swapped). The distributions of the extension axes $S_{\mathrm{hmin}}(\sigma 3)$ of this stage are homogeneous and the axes are sub-horizontal. The exchange of the stress axes $\sigma 1$ and $\sigma 2$ was related to the extensional tectonics.

The direction of this group was computed from NW-SE dykes associated with tension joints and normal faulting. Similar dykes have been dated at 20 Ma in Sinai and Negev (Eyal et al., 1981) The trend of the dykes is parallel to and compatible with the maximum compressive axis of this tensor group. Hence, the age of this stage is referred to $20 \mathrm{Ma}$. These dykes are associated with the opening of the Red Sea.

The stress regime of this stage created conjugated sinistral and dextral strike-slip faults (sinistral movement along NNW-SSE trending faults and dextral movement along WNW-ESE trending faults).

\subsubsection{T5: NNW-SSE to N-S $\mathrm{S}_{\mathrm{Hmax}}$}

The fault-slip data obtained for this direction of stress regime were observed in the Neoproterozoic crystalline 


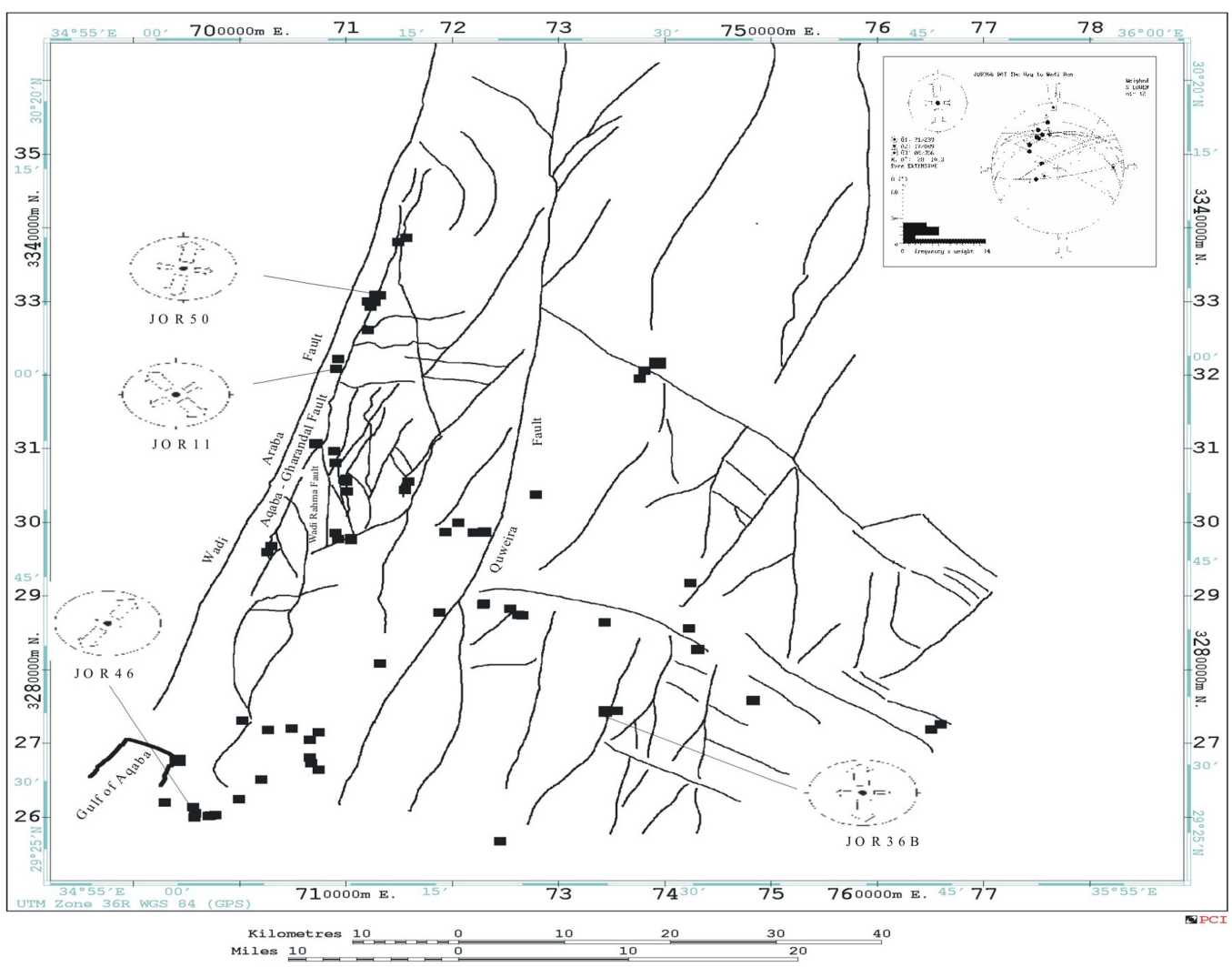

Fig. 10. Structural map with paleostress tensor group T7. Inset: one example of for this group.

basement and the Cambrian, Ordovician, Cretaceous, Palaeocene/Eocene and Miocene rocks.

The principal stress axes of the tensors representing this stage have similar orientation, but with some differences. The results (Table 1) indicate that the mean horizontal stress axes $\sigma 1\left(\mathrm{~S}_{\mathrm{H} \max }\right)$ and $\sigma 3\left(\mathrm{~S}_{\mathrm{hmin}}\right)$ are sub-horizontal, while $\sigma 2$ is sub-vertical. The orientations of these axes are $\sigma 1$ at $02 / 179, \sigma 2$ at $88 / 334$ and $\sigma 3$ at $01 / 089$ while the stress index of 1.79 is indicating a compressive strike-slip regime (transpressive).

Four tensors (Table 1) out of sixteen yield a compressive regime. This means that $\sigma 2$ and $\sigma 3$ are swapped and $\sigma 1$ remains constant. Figure 8 shows examples of tensors obtained in different sites.

$\mathrm{S}_{\mathrm{Hmax}}$ for this group is horizontal with $\mathrm{N}-\mathrm{S}$ orientation $\left(\mathrm{N} 179^{\circ}-359^{\circ} \mathrm{E}\right)$ and $\mathrm{S}_{\mathrm{hmin}}$ is also horizontal with E-W orientation $\left(\mathrm{N} 089^{\circ}-269^{\circ}\right)$. This stress regime reactivated sinistral movement along NE-SW trending faults and dextral movement along NW-SE trending faults but in more shallow conditions (poorly consolidated fault gauge and limonitic coating), thus creating thrust along ENE-WSW trending faults.

\subsubsection{T6: N-S S $\mathrm{H}_{\text {max }}$}

This group is characterised by $\sigma 2$ and $\sigma 3$ being horizontal, $\sigma 1$ vertical and a stress regime index R' of 0.51 , indicating a typical extensive stress regime. The $\mathrm{T} 6$ tensor group was identified in the Dana Conglomerates (Holocene in age; Ibrahim, 1993) or older units suggesting a Holocene age for this deformation. Kinematic indicators include only faults and striations.

The calculated results are listed in Table 1 . These indicate that the distribution of the maximum stress axes $\mathrm{S}_{\mathrm{Hmax}}(\sigma 2)$ and the minimum stress axes $\mathrm{S}_{\mathrm{hmin}}(\sigma 3)$ of this stage are homogeneous and sub-horizontal. Examples of tensors for this stage are shown in Fig. 9.

The mean orientations of the three principal stress axes are $\sigma 1$ at 78/050, $\sigma 2$ at 07/177 and $\sigma 3$ at 09/268. The results indicate a typical extensive stress regime with a N-S $\mathrm{S}_{\mathrm{Hmax}}$ $(\sigma 2)$ and an E-W S $S_{\text {hmin }}(\sigma 3)$. This created NNE-SSW normal faults and NW-SE dextral strike-slip faults, and reactivated NE-SW trending faults as sinistral.

\subsubsection{T7: N-S $\mathrm{S}_{\mathrm{hmin}}\left(\mathrm{E}-\mathrm{W} \mathrm{S}_{\mathrm{H} \max }\right)$}

A group of four tensors with N-S $\mathrm{S}_{\mathrm{hmin}}$ and $\mathrm{E}-\mathrm{W} \mathrm{S}_{\mathrm{Hmax}}$ was obtained in the Dana Conglomerates. Hence, this T7 tensor group is also Holocene in age but younger than the T6 tensor group. All tensors are characterised by $\sigma 2$ and $\sigma 3$ being horizontal and $\sigma 1$ vertical. These tensors are shown in Fig. 10. The results of the palaeostress analysis indicate an extensional regime. Calculations were based on a total of 69 measurements and the results are listed in Table 1. The mean orientations of the three principal stress axes are $\sigma 1$ at 


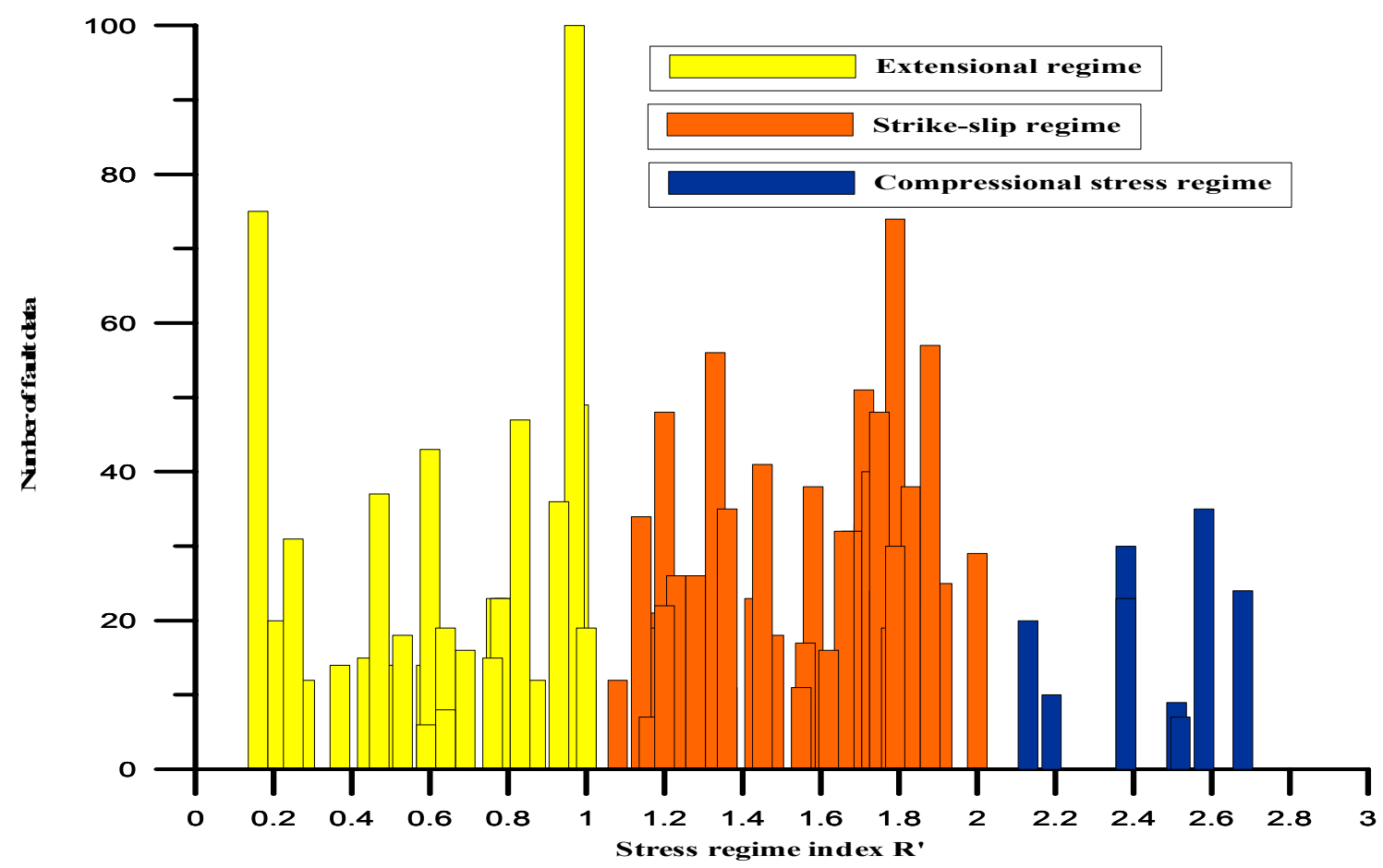

Fig. 11. Bar diagram showing the stress regime index $R$ ' in function of number of fault data.

$86 / 207, \sigma 2$ at $02 / 090$ and $\sigma 3$ at $04 / 360$ and the stress index is 0.33 , indicating a typically extensive stress regime. This stage created E-W to ESE-WNW normal faults, and reactivated NNE-SSW normal faults and NW-SE sinistral faults.

The tensors of this stage are the youngest ones recorded in the study area. However, pull-apart basins in Late Pleistocene-Holocene sediments have been recorded along the Wadi Araba Fault, the southern segment of the Dead Sea Rift. This indicates a strike-slip movement (T8) occurring along the fault, which is younger than the extensive stress regime.

Figure 11 represents the histogram of distribution of the stress regime index $R^{\prime}$ in function of the number of fault data used for the stress inversion. The histogram shows clearly that the main stress regimes are extensional $\left(R^{\prime}=0.16-1.0\right)$ and strike-slip $\left(\mathrm{R}^{\prime}=1.14-2.0\right)$. Few tensors exhibit a compressional stress regime $\left(\mathrm{R}^{\prime}=2.13-2.68\right)$.

\section{Discussion}

The current study presents the first palaeostress results obtained from the kinematic slip data in the eastern margins of the Dead Sea Rift in South-west Jordan.

\subsection{Palaeostress stages and associated tectonic structures}

The analysis of mesostructure measurements and the structural survey in the eastern margins of the Dead Sea Rift enabled the reconstruction of the palaeostress fields of the study area.
Stress inversion of the fault-slip was obtained from rocks ranging in age from Neoproterozoic to Holocene. The data were inverted to determine the palaeostress tensors. A total of 88 different palaeostress tensors have been reconstructed from various sites distributed in the study area.

The fault-slip data used for reconstructing the stress field allow characterising the palaeostress fields and their variation in time. They also allow to analyse the kinematics of the movements along the major faults at different geological stages. Interpretation of the results of stress inversion and relative chronology criteria in function of the stratigraphical constraints lead us to conclude that the study area was subjected to several stress states from the Late Neoproterozoic to the present day. Attention has been drawn to the main stages and characteristics of the deformation of the Dead Sea Rift in order to evaluate the rift's tectonic history.

The data confirm the seven-stage evolution model proposed on the basis of fault-slip data and dyke observations. The major palaeostress regimes differ mainly by the orientation of their principal axis of compression $(\sigma 1)$, by their stress regime index ( $\left.\mathrm{R}^{\prime}\right)$ and by their stratigraphic relationship. There are also indications for a Pleistocene extensional stage. The observation of mesostructures made it possible to reconstruct a consistent succession of the main stress field phases. A regional synthesis of palaeostress evolution for the study area is presented in Fig. 12, based on the computation of mean stress tensors for each stage.

The palaeostress stages (tensor groups) have been successively grouped as follows: two Late Neoproterozoic (T1 and $\mathrm{T} 2$ ), one Cretaceous (T3) and four Cenozoic (T4, T5, T6 and 


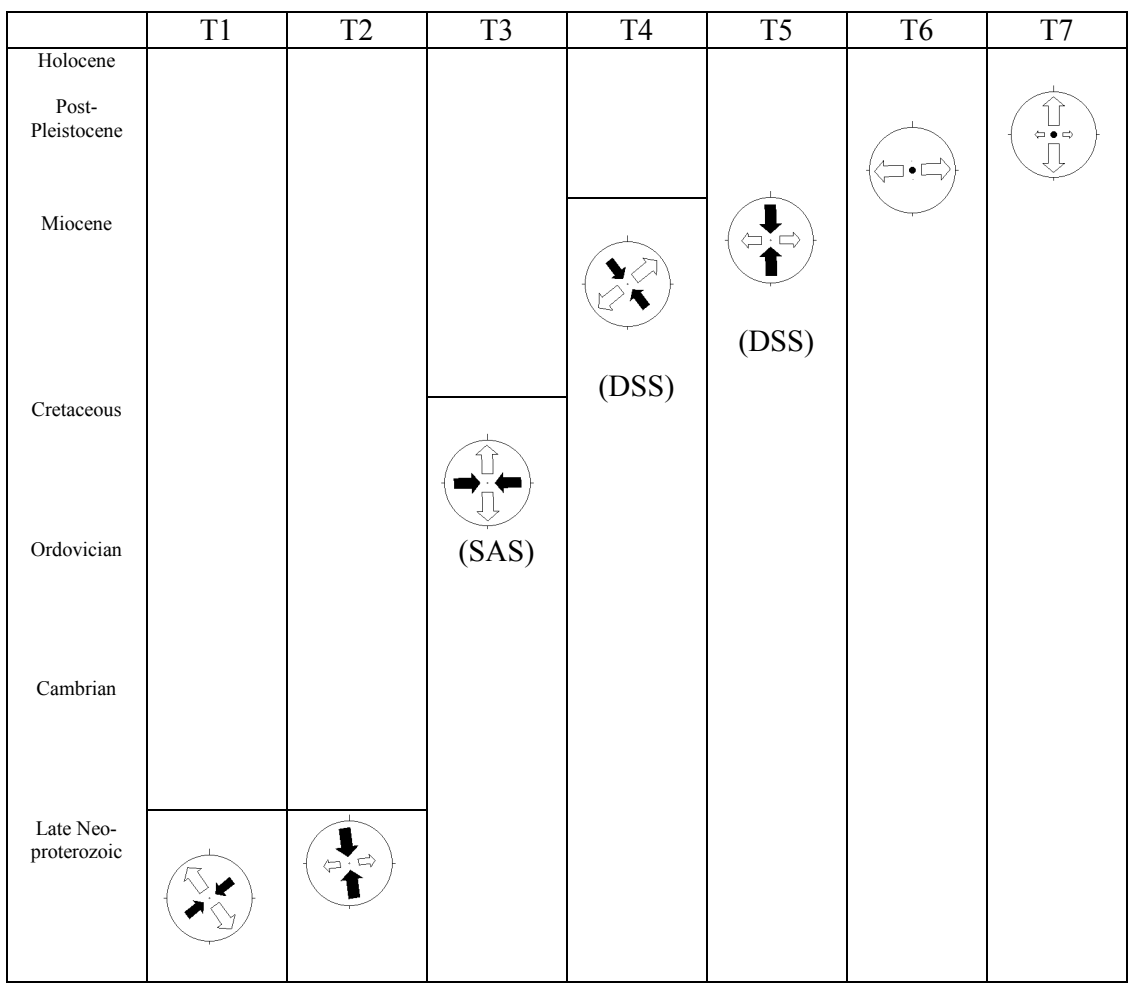

Fig. 12. Summary of the time constraints for the determined palaeostress directions in Southwest Jordan based on computation of the mean stress tensors for each stage. T1: NE-SW $\mathrm{S}_{\mathrm{Hmax}}$, T2: N-S $S_{\text {Hmax }}, \quad T 3:$ E-W $S_{\text {Hmax }}$, T4: NW-SE $S_{\text {Hmax }}$, T5: NNW-SSE to N-S S $S_{\text {Hmax }}$, T6: N-S $S_{\text {Hmax }}$ and T7: E$\mathrm{W} \mathrm{S}_{\mathrm{Hmax}}$.
T7) stress fields were reconstructed. The succession and the age constraint of these events are demonstrated here. These events will be compared with those in the western margins of the Dead Sea Rift in the Sinai sub-plate (part of the African plate).

\subsubsection{T1: NE-SW S $\mathrm{S}_{\text {max }}$}

This group has been divided into two sub-groups: T1a defined from the Late Neoproterozoic dykes, which have a minimum age of $570 \mathrm{Ma}$, and T1b defined from fault-slip data observed only in the Neoproterozoic crystalline basement rocks.

\subsubsection{T1a: NE-SW trending dykes}

Numerous dyke swarms have been observed only in the Neoproterozoic crystalline basement rocks. Therefore, these swarms represent Neoproterozoic activity. Ibrahim and McCourt (1995) interpreted the age of the dykes in South-west Jordan to be 570-560 Ma. In the current study, the NE-SWtrending dykes are interpreted to represent a minimum age of $570 \mathrm{Ma}$.

Four tensors have been constructed from the NE-SWtrending dykes. The results indicate that this sub-group is characterised by a transtensional stress regime with an N062E direction of the maximum principal stress axis $\left(\mathrm{S}_{\mathrm{Hmax}}\right)$. The direction of the maximum principal axis coincides with the trends of the dykes.

Most of the dykes have sharp linear fault contacts with the Neoproterozoic crystalline basement rocks, which im- plies that these dykes have been reactivated during later deformation since striations have been found on their surfaces.

\subsubsection{T1b: NE-SW S Smax}

The earliest indications of displacement along the NNESSW and WNW-ESE-trending faults are of Late Neoproterozoic age. The stress regime that caused the dextral (along NNE-SSW-trending faults) and sinistral (along WNW-ESEtrending faults) activation of these faults has 09/053 of the maximum principal stress axis and is well constrained by 15 stress sites. This stage is characterised by a transtensional stress regime with $\mathrm{R}^{\prime}=1.18$. All these faults have been observed only in the Neoproterozoic crystalline basement rocks. Therefore, this group is Late Neoproterozoic in age. Faults are generally associated with chlorite and/or epidote, which indicate deep brittle deformation. This stress field with NE-SW $\mathrm{S}_{\mathrm{Hmax}}$ does not seem to have been active during the Cambrian.

The T1b tensor group has a similar direction to the T1a group constructed from the NE-SW-trending faults. Both show a transtensional stress regime. Therefore, the fault-slip data of the T1b sub-group are interpreted to be related to the emplacement of the Neoproterozoic NE-trending dykes.

\subsubsection{T2: N-S S}

This group has also been divided into two sub-groups: T2a and $\mathrm{T} 2 \mathrm{~b}$. 


\subsubsection{T2a: NNE-SSW to N-S trending dykes}

A limited amount of N-S-trending dykes have been observed in the Neoproterozoic crystalline basement rocks. These dykes crosscut the NE-SW-trending dykes and hence are younger. The $\mathrm{N}$-S-trending dykes have a maximum age of $560 \mathrm{Ma}$. Due to their limited amount, only one tensor has been constructed with 19 measurements. The results indicate that this sub- group is characterised by a transtensional stress regime with 20/193 of the maximum principal stress axis $\left(\mathrm{S}_{\mathrm{Hmax}}\right)$. This direction coincides with the trends of the dykes.

\subsubsection{T2b: N-S S $\mathrm{Hmax}$}

The observed structures resulting from a N-S $\mathrm{S}_{\mathrm{Hmax}}$, which only affects the Neoproterozoic crystalline basement rocks, are N-S to NNE-SSW sinistral strike-slip faults and E-W reverse faults. The tensors of this group have been constructed from fault planes covered by chlorite or/and epidote, that have been observed only in the Neoproterozoic crystalline basement rocks. The palaeostress results indicate that this stage is characterised by a transpressional stress regime $\left(\mathrm{R}^{\prime}=\right.$ $1.91)$ with a N-S (02/352) orientation of the maximum principal stress axis $\left(\mathrm{S}_{\mathrm{Hmax}}\right)$.

The $\mathrm{S}_{\mathrm{Hmax}}$ of the $\mathrm{T} 2 \mathrm{~b}$ tensor sub-group has a similar direction to the N-S-trending dykes. Therefore, the fault-slip data of the T2b sub-group are considered as related to the emplacement of these dykes.

The effects of the NE-SW $\mathrm{S}_{\mathrm{H} \max }$ and N-S $\mathrm{S}_{\mathrm{Hmax}}$ deformation were observed in the Neoproterozoic crystalline basement rocks only. Therefore, these two groups are Late Neoproterozoic in age. The NE-SW $\mathrm{S}_{\mathrm{Hmax}}$ (T1) corresponds to the major NE trending dyke swarm, while the N-S $\mathrm{S}_{\mathrm{Hmax}}$ (T2) corresponds to a minor and younger N-S trending dyke swarm. Large amounts of Late Neoproterozoic structures have been reactivated during Tertiary times. Good examples are the N-S to NNE-SSW trending faults. On the other hand, the formation of the Dead Sea Rift during the Miocene occurred along the N-S to NNE-SSW trending fault system, which were reactivated as sinistral fault.

These Late Neoproterozoic stages of the study area have not been recognised in earlier work, neither on the eastern nor on the western side of the Dead Sea Rift.

\subsubsection{T3: E-W S $\mathrm{S}_{\text {Hax }}$}

The tensors of this group have been obtained from rocks with an age up to the Cretaceous, and no similar palaeostress tensors were recorded in rocks younger than the Cretaceous. The palaeostress analysis indicates that this stage is characterised by a strike-slip stress regime $\left(\mathrm{R}^{\prime}=1.51\right)$ with a horizontal $05 / 271$ of the maximum principal stress axis $\left(\mathrm{S}_{\mathrm{Hmax}}\right)$. This direction is well constrained from 15 stress sites. In the region of investigation, it is expressed mainly by NW-SE trending sinistral faults and NE-SW trending dextral faults.
This stage corresponds to the Syrian Arc Stress Field (SAS), which has a $\mathrm{S}_{\mathrm{Hmax}}$ oriented E-W to ESE-WNW in adjacent regions of Israel. Eyal and Reches (1983) first obtained the Late Cretaceous Syrian Arc Stress Field (SAS) with maximum horizontal compression axis $\left(\mathrm{S}_{\mathrm{Hmax}}\right)$ trending between E-W to ESE-WNW. However, they claimed that the SAS extended up to the Middle Miocene. Eyal (1996) argued that SAS and DSS are fluctuating since Middle Miocene to the Resent. Ron and Eyal (1985) explained young mesostructures associated with $\mathrm{E}-\mathrm{W}$ to $\mathrm{WNW} \mathrm{S}_{\mathrm{Hmax}}$ by transpression that resulted from the relative N-S movement between the African and Arabian plates along the NNE trending Yammuneh segment of the Dead Sea Transform.

Field relations define the age of the stress regime (T3) as not younger than Cretaceous. The mesostructures related to the Syrian Arc Stress (SAS) in the current study were found in rocks as young as Upper Cretaceous.

\subsubsection{T4: NW-SE $\mathrm{S}_{\mathrm{Hmax}}$}

Tensors of this group have been obtained from up to Palaeocene/Eocene sediments but not younger. The palaeostress results indicate that this stage is characterised by a strike-slip regime $\left(\mathrm{R}^{\prime}=1.31\right)$ with a $05 / 321$ of the maximum principal stress axis $\left(\mathrm{S}_{\mathrm{Hmax}}\right)$. This direction is well constrained by 20 stress sites. The major consequence of the NW-SE $\mathrm{S}_{\mathrm{Hmax}}$ stage was the development of conjugated strike-slip fault sets, oriented NNW-SSE (sinistral) and WNW-ESE (dextral). The palaeostress results suggest that at about the transition from Cretaceous to Miocene a clockwise rotation of about $50^{\circ}$ of the stress field took place.

The tensors represented by this stage have been constructed from fault-slip data and the NW-SE trending doleritic dykes. The NW-SE trending dykes (with a probable age of $20 \mathrm{Ma}$ ) seem to have been emplaced in this stress field. Therefore, a Miocene age for this stage is possible, but this NW-SE compression does not seem to have been active during the Pleistocene. The extension associated with the emplacement of these NW-SE trending dykes is normal to this direction. Thus, the dykes in the study area indicate subhorizontal extension in NE-SW direction. This extension axis agrees in general with the trend of $\sigma 3$ of the Dead Sea Stress Field (DSS). A system of long NW-SE trending dykes has been identified in the southern Sinai and dated by K-Ar at 18-22 Ma (Bartov et al., 1980).

Eyal and Reches (1983) reveal a similar stress regime in the western margins of the Dead Sea Rift in the Israel-Sinai subplate. This implies a regional control of stress regimes rather than some local control. When considering the regional stress field responsible for the formation of tectonic structures, it is important to conduct large-scale investigations over an area, which is wider than the object to be studied. The interaction of the Arabian and the African plates is responsible for the formation of the Dead Sea Rift and the deformation of its margins. The Sinai- Negev Shear Zone, which cuts through Early Miocene dykes, is laterally displaced about $105 \mathrm{~km}$ along the Dead Sea Rift (e.g. Quen- 
nel, 1959). Therefore, the Dead Sea Rift post-dates the Early Miocene (Bartov, 1974). Some investigators suggest that according to local sedimentary and geomorphic evidence and magnetic anomalies in the Gulf of Aden, the main phase of shear along the rift initiated during the Middle Miocene (e.g. Garfunkel, 1981). Others have proposed that the Dead Sea Rift is not older than the Pliocene or even the Pleistocene (e.g. Picard, 1943).

The left-lateral motion along the Dead Sea Rift fits into the NW-SE stress regime in which left-lateral shear acts on roughly N-S trending faults. Therefore, the NW-SE $\mathrm{S}_{\mathrm{H} \max }$ is related to the Dead Sea Stress Field (DSS).

\subsubsection{T5: NNW-SSE to N-S S $\mathrm{S}_{\max }$}

This stage represents a group of tensors obtained from rocks with an age up to the Miocene. The Late Neoproterozoic transpressional stress regime resembles the Pleistocene one with the orientation of the maximum horizontal stress axis $(\sigma 1)$ as nearly N-S. A combination of the ages of outcrops and chlorite or/and epidote mineralization on the fault planes made it possible to separate these two main phases. The NS $\mathrm{S}_{\mathrm{Hmax}}$ of the Late Neoproterozoic were constrained from chlorite or/and epidote on fault planes that were found only in the basement crystalline rocks. In Wadi Rahma, faults in the basement with chlorite or/and epidote mineralization seemed to be intersected by the base of the Cambrian sandstones. Moreover, some other faults, affecting the basement and the Cambrian are filled by calcite veins or coated by haematite.

The dominant $\mathrm{S}_{\mathrm{Hmax}}$ direction for this stage is NNW-SSE to N-S. The stress regime is transpression $\left(\mathrm{R}^{\prime}=1.79\right)$. A major change in tectonic regime occurred in the Pleistocene: a $38^{\circ}$ clockwise rotation of the $\mathrm{S}_{\mathrm{Hmax}}$ direction (from NWSE to NNW-SSE) and a change of the stress regime from strike-slip $(\mathrm{R}=1.31)$ to transpressional $\left(\mathrm{R}^{\prime}=1.79\right)$. This change caused sinistral movement along NE-SW trending faults, dextral movement along NW-SE trending faults and thrust along ENE-WSW trending faults.

Eyal and Reches (1983) and Eyal (1996) recognised a regional stress field with $\mathrm{S}_{\mathrm{Hmax}}$ trending between NNW-SSE and N-S in the Israel-Sinai sub-plate. They attributed this stress field to the Miocene to Holocene Dead Sea Stress Field (DSS). The present study indicates that stress which had a trend similar to that of the Dead Sea Stress Field (DSS) was active beyond the time span suggested for the DSS by Eyal and Reches (1983) and Eyal (1996).

Our results indicate that the Dead Sea Stress Field (Miocene-Pleistocene) has the main horizontal compressional axis $(\sigma 1)$ trending NW in the Miocene and NNW to $\mathrm{N}-\mathrm{S}$ in the Pleistocene. If we accept the suggestion of Quennel (1959) that the sinistral movement of $107 \mathrm{~km}$ along the Dead Sea Rift took place in two stages, we propose that the tensors T4 and T5 are related to these two stages. Quennel (1959) suggested that the first stage with a $62 \mathrm{~km}$ displacement took place in the latest Oligocene-Early Miocene with a $3^{\circ}$ anticlockwise rotation of the Arabian Plate, while the second displacement of $45 \mathrm{~km}$ with a $2.5^{\circ}$ anticlockwise rotation of the Arabian Plate occurred in the Plio-Pleistocene. Hence, the T4 tensors (NW-SE $\mathrm{S}_{\mathrm{Hmax}}$ ) were active in the Miocene, while the T5 tensors (NNW-SSE to N-S $\mathrm{S}_{\mathrm{Hmax}}$ ) are related to the Plio-Pleistocene.

\subsubsection{Extensional stress regimes}

The results show that the study area was affected by two extensional stress regimes (T6 and T7). The stratigraphic control is very clear, and a Post-Miocene age (PliocenePleistocene, covering the last $6 \mathrm{Ma}$ ) is proposed. The minimum stress axis $(\sigma 3)$ trended first E-W, then N-S, while the $\sigma 1$ was mostly vertical. The palaeostress results show that the N-S $S_{\text {hmin }}\left(E-W S_{\text {Hmax }}\right)$ is younger than the E-W $S_{\text {hmin }}$ (N-S $\mathrm{S}_{\mathrm{Hmax}}$ ). Faults constructed the T7 group are cutting those of T6 group. These extensional stress regimes have been inferred from fault-slip data observed in the Dana Conglomerates.

All tensors representing these two extensional stress regimes are restricted to the margin of the Dead Sea Rift. Thus, it is considered as a local stress field, which deformed the eastern margins of the rift. We propose that these extensional stress regimes have been superimposed on the Dead Sea Stress Field (DSS).

\subsubsection{T6: N-S S $\mathrm{S}_{\text {max }}\left(\mathrm{E}-\mathrm{W} \mathrm{S}_{\mathrm{hmin}}\right)$}

The palaeostress results show the existence of a Pleistocene extensional stage (T6) with a N-S $\mathrm{S}_{\mathrm{Hmax}}\left(\mathrm{E}-\mathrm{W} \mathrm{S}_{\mathrm{hmin}}\right)$ stress regime. This stage is characterised by $\mathrm{S}_{\mathrm{Hmax}}$ oriented N177E and is well constrained by 5 stress sites, which represents the T6 tensors group. This stage caused normal faulting along a NNE-SSW trend and reactivated NE-SW trending faults by sinistral movements. A significant normal movement has been found, combined with a small left-lateral component. The observed structures resulting from E-W extension that affect the Dana Conglomerates demonstrate a Late to PostPleistocene age for this stage. The age of the Dana Conglomerates is not precisely determined. This stage occurred after the deposition of the Dana Conglomerates.

The T6 extensional stress regime is restricted to the margin of the Wadi Araba fault. It is therefore considered as a local stress field associated with the latest stage of the Dead Sea Rift. This extension occurred after a transpressional stress regime (NNW-SSE to N-S $\mathrm{S}_{\mathrm{H} \max }$ ) during which $\sigma 1$ is horizontal; then the maximum principal stress axis $(\sigma 1)$ became vertical. The E-W $\mathrm{S}_{\mathrm{hmin}}$ stress regime produced the opening of the Dead Sea Rift.

\subsubsection{T7: E-W $\mathrm{S}_{\mathrm{Hmax}}\left(\mathrm{N}-\mathrm{S} \mathrm{S}_{\mathrm{hmin}}\right)$}

The palaeostress results indicate that this stage is characterised by an extensional stress regime with $02 / 090$ of the maximum principal stress axis $\left(S_{\mathrm{H} \max }\right)$. This direction is well constrained by 4 stress sites. This stage affected also the Dana Conglomerates. It caused E-W to ESE-WNW normal faulting and reactivated NNE-SSW normal faults and NWSE sinistral faults. 
Table 2. Summary of the time constraints for the determined palaeostress directions in the Dead Sea Rift regions

\begin{tabular}{|c|c|c|c|c|c|}
\hline Series & $\begin{array}{l}\text { Current } \\
\text { results } \\
\text { (East of } \\
\text { the Rift) }\end{array}$ & $\begin{array}{l}\text { Eyal \& } \\
\text { Reches } \\
(1983) \\
\text { (West of } \\
\text { the Rift) }\end{array}$ & $\begin{array}{l}\text { Ron \& } \\
\text { Eyal } \\
\text { (1985) } \\
\text { (West of } \\
\text { the Rift) }\end{array}$ & $\begin{array}{l}\text { Eyal } \\
\text { (1996) } \\
\text { (West of } \\
\text { the Rift) }\end{array}$ & $\begin{array}{c}\text { Badawy \& } \\
\text { Horvath } \\
\text { (1999); } \\
\text { Muller et al. } \\
\quad \text { (1997) }\end{array}$ \\
\hline $\begin{array}{l}\text { Holocene } \\
\text { (Present-day } \\
\text { stress field) }\end{array}$ & $\begin{array}{l}\text { NW-SE } \\
\mathrm{S}_{\mathrm{Hmax}}\end{array}$ & & & $\begin{array}{c}\text { SAS } \\
\text { ESE-WNW } \\
\text { S }_{\text {Hmax }}\end{array}$ & $\begin{array}{c}\text { NW-SE } \\
\text { S }_{\text {Hmax }}\end{array}$ \\
\hline $\begin{array}{l}\text { Post- } \\
\text { Pleistocene }\end{array}$ & $\begin{array}{c}\text { T7: E-W } \\
\text { S }_{\text {Hmax }} \\
\text { T6: N-S } \\
\text { S }_{\text {Hmax }}\end{array}$ & & $\begin{array}{c}\mathrm{N}-\mathrm{S} \\
\mathrm{S}_{\mathrm{hmin}}\end{array}$ & & \\
\hline $\begin{array}{l}\text { Miocene / } \\
\text { Pleistocene } \\
\text { (DSS) }\end{array}$ & $\begin{array}{l}\text { T5: NNW- } \\
\text { SSE to N-S } \\
\text { SHmax }_{\text {Hmax }}\end{array}$ & $\begin{array}{l}\text { NNW-SSE } \\
\text { to N-S } \\
\mathrm{S}_{\mathrm{Hmax}}\end{array}$ & & $\begin{array}{c}\text { NNW-SSE } \\
\text { to N-S } \\
\text { S }_{\text {Hmax }}\end{array}$ & \\
\hline $\begin{array}{l}\text { Miocene } \\
\text { (DSS) }\end{array}$ & $\begin{array}{c}\text { T4: NW-SE } \\
S_{H \max }\end{array}$ & $\begin{array}{l}\text { NW-SE } \\
\mathrm{S}_{\mathrm{Hmax}}\end{array}$ & & & \\
\hline $\begin{array}{l}\text { Late } \\
\text { Cretaceous } \\
\text { (SAS) }\end{array}$ & $\begin{array}{c}\text { T3: E-W } \\
\text { S }_{\text {Hmax }}\end{array}$ & $\begin{array}{c}\text { E-W to ESE- } \\
\text { WNW } \\
S_{\text {Hmax }}\end{array}$ & & $\begin{array}{c}\text { ESE-WNW } \\
\mathrm{S}_{\mathrm{Hmax}}\end{array}$ & \\
\hline $\begin{array}{l}\text { Late Neo- } \\
\text { proterozoic }\end{array}$ & $\begin{array}{c}\text { T2: N-S } \\
\text { S Hmax }_{\text {Hmax }}(570) \\
\text { T1: NE-SW } \\
S_{\text {Hmax }}(560)\end{array}$ & & & & \\
\hline
\end{tabular}

$\mathrm{N}-\mathrm{S}$ extension produced E-W normal faults in Southwestern Jordan. This stress is restricted to the margin of the Dead Sea Rift. Thus it is considered as a local stress field which deformed the eastern margins of the rift. This led to N-S extension between the African and Arabian plates.

This stress regime is compatible with the stress regime obtained in the western side of the Dead Sea Rift by Ron and Eyal (1985). They recognised an extensional stress regime with $\sigma 1$ vertical and $\sigma 3\left(\mathrm{~S}_{\mathrm{hmin}}\right)$ oriented $\mathrm{N}-\mathrm{S}$. They attributed this extension to have been active since post-Middle Pliocene times producing E-W normal faults.

\subsubsection{T8: Present-day Stress field}

The data provided by World Stress Map (Muller et al., 1997) indicate that the present-day Stress Field in the Dead Sea Rift area has a NW-SE $\mathrm{S}_{\text {Hmax }}$ (T8). Pull-apart basins were observed along the Wadi Araba fault indicating a strike-slip regime with $\mathrm{S}_{\mathrm{Hmax}}$ oriented NW-SE, but it was not possible to constrain the orientation of this stress regime.

The evolution of the stress field from a strike-slip regime in the Cretaceous to a pure extensional regime in the Pleistocene and then back again to a strike-slip regime in the present days is evidenced for the Dead Sea Rift. This means that sinistral movements compatible with the Dead Sea Stress are still active.

The palaeostress tensors reconstructed from the fault-slip data in the study area indicate that the Syrian Arc Stress (SAS) affected pre-Upper Cretaceous rocks, while the Dead
Sea Stress (DSS) was active from the Miocene onwards till today.

Table 2 represents a summary of the time constraints for the determined palaeostress directions in the Dead Sea Rift region. It shows the palaeostress directions of this study and the previous regional investigations.

In summary, the evolution of the Dead Sea Rift shows a general clockwise rotation of the $\mathrm{S}_{\mathrm{Hmax}}$ axis with time. Two stages can be distinguished in this rotation. The older one marks the change of the $\mathrm{S}_{\mathrm{Hmax}}$ axis from E-W to NW-SE at $50^{\circ}$ rotation, taking place in the Miocene. The second one marks the changes of the $\mathrm{S}_{\mathrm{Hmax}}$ axis from NW-SE to NNW$\mathrm{SSE}$ to $\mathrm{N}-\mathrm{S}$ at $38^{\circ}$ rotation, dating from the Pleistocene.

\section{Initiation and development of the Dead Sea Rift}

Transform faults in continents can be expected to follow preexisting zones of weakness, such as older faults that might originally have been of a different type. The current study shows such a zone of weakness along N-S to NNE-SSW trending faults that have been formed during the Late Neoproterozoic. This implies that the Late Neoproterozoic structures were reactivated during the Cainozoic and controlled the recent movement along the Dead Sea Rift. The movement along the Dead Sea Rift began in Tertiary times. The current study provides indications of a possible initial breakup of the African-Arabian Shield already in the Late Neoproterozoic that was reactivated in the Tertiary. 
The E-W compression (SAS, our stage T3) is acting at a high angle with the Dead Sea Rift. It did not reactivate the rift but it created a series of conjugated strike-slip faults, witnessing the crustal weakness in this area before the development of the rift.

The current study shows the existence of both strike-slip and normal faulting. The strike-slip faults are vertical to subvertical with horizontal striations, which can not create the depression. The normal faults are inclined at about $60^{\circ}$ with a dip-slip sense that created the rift. Therefore, we propose that the Dead Sea-Wadi Araba-Gulf of Aqaba depression has undergone both strike-slip (pull-apart type) and extensional (graben type) tectonics, in general a transcurrent plate boundary between the Arabian and African plates. Extension seems to be subsequent to initial strike-slip reactivation.

\section{Conclusions}

This study has pointed out the tectonic evolution of the Wadi Araba Segment of the Dead Sea Rift in terms of deformation stages and related stress fields. A succession of seven brittle tectonic regimes has been established from microtectonic observations and structural studies on faults from Neoproterozoic to Pleistocene times in the eastern margins of the Dead Sea Rift, South-west Jordan. They are characterised by the following succession of stress fields.

The first two tensor groups were obtained from the Late Neoproterozoic (between 570 and 560 Ma old) dyke swarm, and the fault-slip data related to this dyke emplacement.

The other tensor groups are related to Cretaceous and younger deformation stages. The third stage (T3) has a strike-slip stress regime with an E-W $\mathrm{S}_{\mathrm{Hmax}}$ that affected all pre-Tertiary series. This represents the Syrian Arc Stress Field (SAS).

The next stage (T4) is characterised also by a strike-slip stress regime, but with a NW-SE $\mathrm{S}_{\mathrm{Hmax}}$. It affected the Palaeocene/Eocene rocks but not Miocene rocks, while NWSE trending dykes (with a probable age of about 20 Ma) seem to have been emplaced in this stress field. Therefore, a Miocene age for this stage seems plausible. It is followed by a transpressional stage (T5), with a NNW-SSE to N-S S $\mathrm{Smax}_{\text {max }}$ affecting rocks with an age up to the Plio-Pleistocene. These last two stages (T4 and T5) correspond to the Dead Sea Stress Field (DSS).

In addition, post-Pleistocene extensional stages (T6 and T7) were evidenced from the fault-slip data that affected the Dana Conglomerates with $\mathrm{T} 7$ being the youngest. T6 has an E-W $S_{\text {hmin }}$ and T7 has a N-S $S_{\text {hmin }}$.

The Late Pleistocene-Holocene sinistral strike-slip deformation (T8) related to the Wadi Araba Fault shows that strike-slip movements compatible with the Dead Sea Stress field are still active.

It can be concluded that the new palaeostress data evidence a general clockwise rotation with time of the $S_{H \max }$ axis from an E-W trend in the Cretaceous towards a N-S trend in the Pleistocene. Two regional progressive rotations of the stress regime direction have been inferred. One took place in the Miocene from E-W to NW-SE at about $50^{\circ}$ rotation and the second in the Pleistocene from NW-SE to NNW-SSE at about $38^{\circ}$ rotation. The palaeostress data also show the appearance of E-W extension in the Late Pleistocene, superimposed on the Dead Sea Stress Field (DSS). We therefore suggest that the Dead Sea Rift system has a combination of strike-slip and dip-slip movements.

Acknowledgements. The authors thank the PEACE program and the Al Azhar University of Gaza for the financial support given to Usama Zain Eldeen through a Ph.D scholarship during the research period. They also thank the Ghent University and the Royal Museum for Central Africa, Belgium, for providing financial support for the fieldwork.

\section{References}

Angelier, J.: Fault slip analysis and palaeostress reconstruction, in: Hancock, P. L. (Ed.): Continental Deformation, Pergamon, Oxford, 101-120, 1994.

Angelier, J. and Mechler, P.: Sur une méthode graphique de recherche des contraintes principales également utilisable en tectonique et en séismologie: 1a méthode des dièdres droits, Bull. Soc. Géol. France, 7(19), 1309-1318, 1977.

Badawy, A. and Horvath, F.: Recent stress field of the Sinai subplate region, Tectonophysics, 304, 385-403, 1999.

Bahat, D. and Rabinovitch, A.: The initiation of the Dead Sea Rift, Journal of Geology, 5, 591-601, 1983.

Bartov, J.: A structural and paleographic study of the Central Sinai faults and domes, Ph.D. thesis, Hebrew University, Jerusalem (English abstract), 1974.

Bartov, J., Steinitz, G., Eyal, M., and Eyal, Y.: Sinistral movement along the Gulf of Aqaba - Its age and relation to the opening of the Red Sea, Nature, 285, 220-222, 1980.

Bender, F.: Geological map of Jordan - 1:250000 sheets Amman and Aqaba-Ma'an, Hannover (Bundesamt für Bodenforschung), 1968.

Bender, F.: The shear along the Dead Sea Rift: Discussion, Royal Society of London Philosophical Transaction, series. A, 167, 127-129, 1970.

Bender, F.: Geology of the Arabian Peninsula, Jordan., 36 pp., 1975.

Ben Menahem, A., Nur, A., and Vered, M.: Tectonics, seismicity and structure of the Afro-Eurasian junction - The breaking of an incoherent plate, Physics of the Earth and Planetary Interiors, 12, 1-50, 1976.

Bentor, Y. K. and Vorman, A.: A structural contour map of Israel, scale 1:250 000 with remarks on its dynamic interpretation, Israel Geological Survey Bulletin, 7, 10 pp, 1954.

Bott, M. H. P.: The mechanism of oblique slip faulting, Geological Magazine, 96, 109-117, 1959.

Delvaux, D.: The TENSOR program for palaeostress reconstruction: examples from the East African and the Baikal rift zones, Terra Abstract, Abstract Supplement No.1, to Terra Nova, 5, 216, 1993.

Delvaux, D., Moeys, R., Stapel, G., Petit, C., Levi, K., Miroshnichenko, A., Ruzhich, V., and San'kov, V.: Palaeostress reconstructions and geodynamics of the Baikal region, Central Asia, part II, Cenozoic rifting, Tectonophysics, 282, 1-38, 1997. 
De Sitter, L. U.: Structural development of the Arabian Shield in Palestine, Geologie en Mijnbouw, 41, 116-124, 1962.

Eyal, Y.: Stress field fluctuation along the Dead Sea rift since the middle Miocene, Tectonics, 15, 1, 157-170, 1996.

Eyal, Y. and Reches, Z.: Tectonic analysis of the Dead Sea Rift region since the Late Cretaceous based on mesostructures, Tectonics, 2, 167-185, 1983.

Eyal, M., Eyal, P., Bartov, Y., and Steinitz, G.: The tectonic development of the western margin of the Gulf of Elat (Aqaba) rift, Tectonophysics, 80, 39-66, 1981.

Freund, R.: A model of the structural development of Israel and adjacent areas since Upper Cretaceous times, Geological Magazine, 102, 189-205, 1965

Freund, R.: The geometry of faulting in the Galilee, Israel Journal of Earth Sciences, 19, 117-140, 1970.

Freund, R., Zak, I., and Garfunkel, Z.: Age and rate of the sinistral movement along the Dead Sea Rift, Nature, 220, 253-255, 1968.

Freund, R., Zak, I., Goldberg, M., Weissbrod, T. and Derin, B.: The shear along the Dead Sea Rift, Philosophical Transactions of the Royal Society of London, Series A, 267, 107-130, 1970.

Garfunkel, Z.: Tectonic of the western margin of the southern Arava, Ph.D. thesis, Hebrew University, Jerusalem, 204 pp. (English abstract), 1970.

Garfunkel, Z.: Internal structure of the Dead Sea leaky transform (rift) in relation to plate kinematics, Tectonophysics, 80, 81-108, 1981.

Garfunkel, Z. and Bartov, Y.: The tectonic of the Suez Rift, Israel Geological Survey, 71, 44 pp, 1977.

Garfunkel, Z., Zak, I., and Freund, R.: Active faulting in the Dead Sea Rift, in: Freund, R. and Garfunkel, Z. (Eds): The Dead Sea Rift, Tectonophysics, 80, 1-26, 1981.

Hatzor, Y. and Reches, Z.: Structure and palaeostress in the Gilboa' region, western margin of the central Dead Sea rift, Tectonophysics, 180, 87-100, 1990.

Ibrahim, K.: The geology of the Wadi Gharandal area, Map sheet 3050 II. Natural Resources Authority, Amman, Jordan, 1993.

Ibrahim, K. and McCourt, W. J.: Neoproterozoic granitic magmatism and tectonic evolution of the northern Arabian Shield: evidence from Southwest Jordan, Journal of African Earth Sciences, 20, 2, 103-118, 1995.

Lartet, L.: Essay on the geology of Palestine, Ann. Sci. Géol., Paris, Soc. Géol. France, 1, 17-18, 1869.

Letouzey, J., and Tremolieres, P.: Palaeostress field around the Mediterranean derived from microtectonics: Comparison with plate tectonic data, Rock Mechanics, 9, 173-192, 1980.

Lyberis, N., Yurur, T., Chorowicz, J., Kasapoglu, E., and Gun- dogdu, N.: The East Anatolian Fault: an oblique collisional belt, Tectonophysics, 204, 1-15, 1992.

Michelson, H.: Geological Survey of the Golan Heights, Tahal, Tel Aviv, 1982.

Michelson, H., Flexer, A., and Erez, Z.: A comparison of the eastern and western sides of the Sea of Galilee and its implication on the tectonics of the northern Jordan Rift Valley, Tectonophysics, 141, 125-134, 1987.

Muller, B., Sperner, B., Theune, U., and Fuchs, K.: The World Stress Map Project (WSM), Heidelberg Academy of Science and Humanities; Geophysical Institute, University of Karlsruhe, Germany, 1997.

Neev, D.: Tectonic evolution of the Middle East and the Levantine Basin (easternmost Mediterranean), Geology, 3, 683-686, 1975.

Picard, L.: Structural evolution of Palestine, with comparative notes on neighboring countries, Geol. Dep. Hebrew University, Jerusalem, Bulletin, 4, 1-134, 1943.

Picard, L.: The geological evolution of the Quaternary in the central-northern Jordan graben, Israel, Geological Society of America, Spec. Paper, 84, 337-366, 1965.

Picard, L.: Thoughts on the graben system in the Levant, Geological Survey, Canada, Pap., 66-14, 22-32, 1967.

Picard, L.: The Elat (Aqaba)-Dead Sea-Jordan subgraben system, Tectonophysics, 141, 23-32, 1987.

Quennell, A. M.: Geological map of Jordan (East of the Rift valley), 1:250 000 sheets Kerak and Ma'an, Amman, Jordan, 1956.

Quennell, A. M.: Tectonics of the Dead Sea Rift, Proc. 20th Inter. Geol. Congr., Mexico, 1956, Assoc. de Serv. Géol. Afr., 385403, 1959.

Reches, Z., Hoexter, D. F., and Hirsch, F.: The structure of a monocline in the Syrian-Arc System, Middle East - Surface and subsurface analysis, Journal of Petroleum Geology, 3, 413-425, 1981.

Ron, H. and Eyal, Y.: Intraplate deformation by block rotation and mesostructures along the Dead Sea transform, northern Israel, Tectonics, 4, 85-105, 1985.

von Buch, L.: Letter in Robinson, E.: Biblical Researches in Palestine, 2, appendix, London, 673-675, 1841.

Vorman, A. J.: On the Red Sea Rift problem, Bull. Res. Counc. Israel, 10G, 321-338, 1961.

Zak, I. and Freund, D.: Recent strike-slip movements along the Dead Sea Rift, Israel Journal of Earth Sciences, 15, 33-37, 1966.

Zak, I. and Freund, D.: Asymmetry and basin migration in the Dead Sea rift, in: Freund, R. and Garfunkel, Z. (Eds.): The Dead Sea Rift, Tectonophysics, 80, 27-38, 1981. 